\title{
THE
}

\section{South Atlantic mass transports obtained from subsurface float and hydrographic data}

\author{
Regina R. Rodrigues \\ Mark Wimbush \\ University of Rhode Island, mwimbush@uri.edu \\ D. Randolph Watts \\ University of Rhode Island, randywatts@uri.edu \\ Lewis M. Rothstein \\ University of Rhode Island, Irothstein@uri.edu \\ Michel Ollitrault \\ Follow this and additional works at: https://digitalcommons.uri.edu/gsofacpubs
}

The University of Rhode Island Faculty have made this article openly available.

Please let us know how Open Access to this research benefits you.

This is a pre-publication author manuscript of the final, published article.

Terms of Use

This article is made available under the terms and conditions applicable towards Open Access

Policy Articles, as set forth in our Terms of Use.

\section{Citation/Publisher Attribution}

Rodrigues, R. R., Wimbush, M., Watts, D. R., Rothstein, L. M., \& Ottirault, M. (2010). South Atlantic mass transports obtained from subsurface float and hydrographic data. Journal of Marine Research, 68(6), 819-850. doi: 10.1357/002224010796673858

Available at: https://doi.org/10.1357/002224010796673858

This Article is brought to you for free and open access by the Graduate School of Oceanography at DigitalCommons@URI. It has been accepted for inclusion in Graduate School of Oceanography Faculty Publications by an authorized administrator of DigitalCommons@URI. For more information, please contact digitalcommons-group@uri.edu. 


\title{
South Atlantic mass transports obtained from subsurface float and hydrographic data
}

\author{
Regina R. Rodrigues ${ }^{1,2, ~}{ }^{*}$, Mark Wimbush ${ }^{1}$, D. Randolph Watts ${ }^{1}$, Lewis M. Rothstein ${ }^{1}$, \\ Michel Ollitrault ${ }^{3}$
}

\author{
${ }^{1}$ Graduate School of Oceanography, University of Rhode Island, Narragansett, RI, USA \\ ${ }^{2}$ Current address. Department of Environmental Engineering, Federal University of Santa Catarina, Santa \\ Catarina, Brazil. \\ ${ }^{3}$ Laboratoire de Physique des Océans, IFREMER Centre de Brest, France \\ *: Corresponding author : Regina R. Rodrigues, email address : regina.rodrigues@ens.ufsc.br
}

\begin{abstract}
:
Mean total (barotropic + baroclinic) mass transports of the oceanic top 1000 dbar are estimated for two regions of the South Atlantic between $18^{\circ} \mathrm{S}$ and $47^{\circ} \mathrm{S}$. These transports are obtained by using Gravest Empirical Mode (GEM) fields calculated from historical hydrography with temperature and position data from quasi-isobaric subsurface floats deployed from 1992 through 2001. The float-GEMestimated total mass transports reveal a Brazil Current with a southward flow of $20.9 \mathrm{~Sv}$ at $30^{\circ} \mathrm{S}$ and $46 \mathrm{~Sv}$ at $35^{\circ} \mathrm{S}\left(1\right.$ Sverdrup, Sv $\left.=10^{6} \mathrm{~m}^{3} \mathrm{~s}^{-1}\right)$. Two recirculation cells are identified in the southwest corner of the subtropical gyre north of $40^{\circ} \mathrm{S}$, one centered at $48^{\circ} \mathrm{W}, 37^{\circ} \mathrm{S}$ recirculating $28.5 \mathrm{~Sv}$ and another centered at $40^{\circ} \mathrm{W}, 38^{\circ} \mathrm{S}$ recirculating $13.9 \mathrm{~Sv}$. The South Atlantic Current (SAC) flows eastward with $50 \mathrm{~Sv}$ at $30^{\circ} \mathrm{W}$ and splits into two branches in the east, one north of $38^{\circ} \mathrm{S}$ transporting $19 \mathrm{~Sv}$ and one south of $41^{\circ} \mathrm{S}$ transporting $31 \mathrm{~Sv}$. Of the $39.7 \mathrm{SV}$ of SAC transport that comes from the Malvinas Current/Antarctic Circumpolar Current (ACC) system in the western basin, only 8.7 Sv flow with the northern branch and the remaining $31 \mathrm{~Sv}$ flow as the southern branch out of the South Atlantic rejoining the ACC directly (20.6 Sv) or interacting with the Agulhas Current Retroflection (10.4 Sv). From the northern branch, only 4.7 Sv of Malvinas Current/ACC origin and $10.3 \mathrm{~Sv}$ of Brazil Current origin (a total of $15 \mathrm{~Sv}$ ) stays in the South Atlantic forming the Benguela Current, recirculating within the subtropical gyre. The Agulhas Current Retroflection reaches westward as far as $10^{\circ} \mathrm{E}$ with a transport of $48 \mathrm{~Sv}$. In terms of mean total transport, the cold-water route carries $4.7 \mathrm{~Sv}$ in the upper 1000 dbar whereas the warm-water route carries $8.5 \mathrm{~Sv}$. However, considering the interaction between waters from both origins, there is a total of $19.1 \mathrm{~Sv}$ of waters entering the Cape Basin from the Pacific Ocean and 18.5 Sv from the Indian Ocean.
\end{abstract}




\section{Introduction}

The upper-layer circulation of the South Atlantic comprises an anticyclonic subtropical gyre and a cyclonic sub-equatorial gyre, as well as mainly zonal equatorial and circumpolar current systems (Peterson and Stramma, 1991; Stramma and England, 1999). The Brazil Current is the western boundary current of the South Atlantic subtropical gyre. It flows southward along the South America coast until it encounters the Malvinas Current and forms the South Atlantic Current (SAC). The SAC flows eastward across the South Atlantic to feed the eastern-boundary Benguela Current. The latter becomes the South Equatorial Current (SEC), which in turn bifurcates as it approaches the coast of South America, closing the subtropical gyre by feeding the Brazil Current to the south.

Upper and intermediate waters from the Pacific and Indian Oceans enter the South Atlantic via cold- and warm-water routes, respectively (Gordon, 1985, 1986; Rintoul, 1991; de Ruijter et al., 1999; Speich et al., 2001). Their water properties then propagate through the upper South Atlantic to the northern North Atlantic, where they influence the process of deep-water formation, i.e., the meridional overturning circulation (MOC). Thus thermohaline fluxes through the South Atlantic affect global heat transports and budgets, as well as mass and heat exchanges with the atmosphere (Trenberth and Solomon, 1994).

Because it transports heat equatorward, the South Atlantic plays a critical and distinctive role in the global thermohaline circulation. But our knowledge, on the basin scale, of its largely wind-driven upper and intermediate circulation is sparse. Nevertheless, during the last two decades, a number of surveys have been conducted, largely through the World Ocean Circulation Experiment (WOCE), and as result a better data set is now available for the South Atlantic Ocean, including both hydrographic data and subsurface-float data. Even though the WOCE data 
have provided a more accurate view of the circulation for specific areas, a large-scale view of the South Atlantic circulation obtained in a consistent way is still missing. Moreover, estimates of mean absolute transports are not available. We need a uniform method that is suited for meandering eddying currents and a reference velocity field to provide estimates of absolute transport. We also need to utilize as much of the available data as possible to cope with the sparseness of observations. Our purpose is to use the WOCE data in a manner that combines the density profiles and float temperature and position measurements to produce maps of estimated baroclinic, barotropic, and total transports. In particular, we seek to quantify the relative contributions into the South Atlantic of colder and warmer waters respectively from Pacific and Indian Ocean origins. According to Biastoch et al. $(2008,2009)$, there has been a change in the circulation of the South Atlantic subtropical gyre and Agulhas leakage in the last three decades due to changes in the wind stress field. This has critical implications for the MOC. Hence, it is important to know the mean state of the subtropical gyre and the mean contributions of the cold and warm routes for comparisons with future observational studies.

Data from RAFOS and MARVOR floats in the western South Atlantic (Boebel et al., 1999a,b,c; Ollitrault, 1999) and the Agulhas Current Retroflection region (Boebel et al., 2000, 2003) for the period of 1992-2001 are used here in conjunction with the Gravest Empirical Mode (GEM) technique to estimate the mean structure of the hydrographic fields of the region. The GEM is an efficient method for projecting the hydrographic data from regions around strong currents, such as the Brazil, South Atlantic, and Agulhas Currents, into geostrophic streamfunction space (Meinen and Watts, 2000; Sun and Watts, 2001). The procedure is to use the float position data in a piecewise Eulerian way to estimate velocity vectors, and in addition use each float measurement of temperature and pressure to look up (via the GEM tables) vertical 
profiles of the desired hydrographic variables. Thus, at each position along its path, each float supplies an absolute velocity vector and an estimated profile of temperature, salinity, and specific volume anomaly. This is the so-called "float-GEM" method, developed by PérezBrunius et al. (2004a,b) for use with data from isopycnal floats.

The main objective of this study is to adapt the float-GEM technique for use with data from isobaric floats (available for the South Atlantic) and thereby estimate mean absolute transports in the upper $1000 \mathrm{dbar}$ of the South Atlantic subtropical gyre using a uniform methodology. Section 2 describes how the GEM fields are constructed and combined with the float data (position, pressure, and temperature), and how the suite of many float "velocities" and "pseudo-casts" is used to generate maps of mean barotropic, baroclinic, and total (absolute) transports. In Section 3, the float-GEM technique is tested by simulating float data from two WOCE hydrographic transects. Mean mass transports are discussed in Section 4. Finally, Section 5 presents a summary and conclusions.

\section{Methods}

a. GEM Fields

A GEM field is a projection of hydrographic data onto geostrophic streamfunction space. In this study, the indices are (1) geopotential anomaly referenced to $1000 \mathrm{dbar}$, and (2) pressure, so the GEM is an empirical lookup table between geopotential anomaly and vertical profiles of temperature $(T)$, salinity $(S)$, or specific volume anomaly $(\delta)$.

We used the following procedure to develop GEM fields for the South Atlantic. Qualitycontrolled CTD and bottle data were obtained for the region $18^{\circ}-50^{\circ} \mathrm{S}, 60^{\circ} \mathrm{W}-30^{\circ} \mathrm{E}$ from HydroBase (Curry, 1996) and from the Alfred Wegener Institute (AWI) data set (Olbers et al., 
1992) (3503 casts used, see black dots in Fig. 1). The $T$ and $S$ data are used to calculate specific volume anomaly $\delta(S, T, p)=\rho^{-1}(S, T, p)-\rho^{-1}(35,0, p)$ and geopotential anomaly referenced to $1000 \mathrm{dbar} \phi_{1000}=\int_{0}^{1000 \mathrm{dbar}} \delta(S, T, p) d p$. A correction for seasonal variations in the uppermost 100 dbar was applied to the parameter $\phi_{1000}$. The resulting deseasoned data $\left(\phi_{1000}\right)$ were used to create two-dimensional mean GEM fields of $T$ and $\delta$; specifically, at each pressure level, the property values were fitted with a cubic smoothing spline as a function of $\phi_{1000}$ (see Fig. 2).

The GEM fields were calculated for four smaller subregions of the whole domain (Fig. 1) to obtain empirical relationships between $\phi_{1000}$ and the profiles of $T$ and $\delta$, reflecting the spatial variability of hydrographic conditions across the area of study. These subregions are defined according to hydrographic conditions and availability of data. They slightly overlap each other $\left(2^{\circ}\right)$ meridionally to smooth the transition between the GEM fields. They are separated zonally by the $15^{\circ} \mathrm{W}$ meridian, which corresponds approximately to the axis of the Mid-Atlantic Ridge. The $35^{\circ} \mathrm{S}$ parallel is used to separate the northern and southern parts of the region because it represents the subtropical gyre axis. The four subregions, shown in Figure 1, are northwest (NW: $\left.18^{\circ}-36^{\circ} \mathrm{S}, 60^{\circ}-15^{\circ} \mathrm{W}\right)$, southwest $\left(\mathrm{SW}: 34^{\circ}-50^{\circ} \mathrm{S}, 60^{\circ}-15^{\circ} \mathrm{W}\right)$, northeast $\left(\mathrm{NE}: 18^{\circ}-36^{\circ} \mathrm{S}, 15^{\circ} \mathrm{W}-\right.$ $\left.20^{\circ} \mathrm{E}\right)$, and southeast (SE: $\left.34^{\circ}-50^{\circ} \mathrm{S}, 15^{\circ} \mathrm{W}-30^{\circ} \mathrm{E}\right)$. The SW subregion $T$ and $\delta$ GEM fields are shown in Figure 2 as an example. They reflect the familiar water mass structure in that region.

Clearly, different vertical profiles of $\delta$ can generate the same vertically integrated $\phi_{1000}$, because the integral does not uniquely determine the integrand. Nevertheless, using historical hydrography from many years and seasons in the studied area, each value of $\phi_{1000}$ is found to be associated with similar profiles of both $T$ and $S$. Figure 3a shows groups of CTD-measured temperature profiles for the SW subregion; each profile in a group has a $\phi_{1000}$ value within $0.2 \mathrm{~m}^{2}$ $\mathrm{s}^{-2}$ of a central value ( 7 to $11 \mathrm{~m}^{2} \mathrm{~s}^{-2}$, depending on the group). The corresponding temperature 
GEM profile is also plotted and is seen to represent well the overall structure of each measured profile within the group.

As in Sun and Watts (2001), we use a percentage variance ratio $(\gamma)$ to examine how well the GEM fields represent the thermohaline fields in each South Atlantic subregion. At a pressure level $p$ this ratio

$$
\gamma(p)=\frac{\sigma_{g}^{2}}{\sigma^{2}}=\frac{\sigma^{2}-\sigma_{r}^{2}}{\sigma^{2}}=1-\frac{\sigma_{r}^{2}}{\sigma^{2}}
$$

represents the fraction of the total hydrographic variance captured by the GEM field. Here subscript $g$ means GEM field, $r$ the residuals of the hydrocasts relative to the GEM field, and the variance $\sigma^{2}$ is

$$
\sigma^{2}=\left\langle(T-\bar{T})^{2}\right\rangle=\left\langle\left(T_{g}+T_{r}-\bar{T}\right)^{2}\right\rangle=\sigma_{g}^{2}+\sigma_{r}^{2}
$$

for temperature, and similarly for the other parameters. Thus $\gamma$ is the ratio of the variance of the spline fit to that of the data at each pressure level (i.e., variances of the pink curves and blue dots, respectively, in the bottom six panels of Fig. 2).

Figure $3 \mathrm{~b}$ shows $\gamma$ for $T$ and $\delta$ for the top $1000 \mathrm{dbar}$ of all four subregions. The GEM fields capture up to $98 \%$ of the variance of the $T$ and $\delta$ data at various depths for the South Atlantic. Averaging $\gamma$ over 100-1000 dbar for $T$ and $\delta$, we find that these two fields capture more than $40 \%$ of the variability for the NW subregion, $90 \%$ for the SW subregion, $80 \%$ for the NE subregion, and $95 \%$ for the SE subregion. The GEM fields capture a lesser proportion of variability near the surface due to additional scatter of the data at pressure levels above $100 \mathrm{dbar}$ (Fig. 3a) related to variable exchanges with the atmosphere (interannual variability, for instance). The relatively low variance ratio for the NW and NE subregions is mainly due to low variance of the temperature and salinity fields in these regions (Rodrigues, 2004). 


\section{b. Float-GEM Technique for Isobaric Floats}

Pérez-Brunius et al. (2004a,b) developed the float-GEM technique for isopycnal-float data from the northern North Atlantic. Here we modify the technique for use with data from quasiisobaric floats, since such data are more abundant not only in the South Atlantic but also in other oceans. Additionally we estimate here the true absolute geostrophic mass transport, which becomes an increasingly important distinction as latitudes decreases. We apply the float-GEM technique to two areas of the South Atlantic, a western area $18^{\circ} \mathrm{S}-45^{\circ} \mathrm{S}, 55^{\circ} \mathrm{W}-27^{\circ} \mathrm{W}$ and an eastern area $27^{\circ} \mathrm{S}-47^{\circ} \mathrm{S}, 7^{\circ} \mathrm{W}-30^{\circ} \mathrm{E}$ (Fig. 4). These limits are chosen according to availability of the float data, except in the case of the $18^{\circ} \mathrm{S}$ limit: north of this latitude the technique does not work well in the western South Atlantic because the single-index GEM lookup tables fail to capture most of the hydrographic variance.

Isobaric floats providing data used in this study are: 1) RAFOS floats deployed and tracked during the Deep Basin Experiment in the western South Atlantic from 1992 to 1996 (75 floats) and the Cape of Good Hope Experiment (KAPEX) in the eastern South Atlantic from 1997 to 1999 (34 floats); and 2) MARVOR floats deployed and tracked during the Subantarctic Motions in the Brazil Basin (SAMBA) Experiment in the western South and equatorial Atlantic from 1994 to 2001 (100 floats). They were ballasted to follow intermediate waters between 700 and 1000 dbar (Ollitrault et al., 1994, 1995; Ollitrault, 1999; Boebel et al., 1999a, 2000).

The combined RAFOS and MARVOR float data consist of 19,217 locations within the two areas (Fig. 4a). Measurements of pressure $p_{\text {float}}$, temperature $T_{\text {float }}$, location $\vec{X}_{\text {float }}$ (and hence

velocity $\vec{V}_{\text {float }}$ ) at time $t_{\text {float }}$ are treated as a station measurement. In other words, the float data are used in an Eulerian way. At any given station, $\vec{X}_{\text {float }}$, the geostrophic streamfunction, $\phi_{f l o a t}$ (geopotential anomaly referenced to $1000 \mathrm{dbar}$ ), is obtained by looking up the $\left(p_{\text {float }}, T_{\text {float }}\right)$ pair in 
the corresponding temperature-GEM lookup table (Fig. 5). In turn, $\phi_{f l o a t}$ is used to estimate vertical profiles of specific volume anomaly $\left(\delta_{f g}\right)$ from its GEM field. Hereafter, the subscript $f g$ means "float-GEM". Having obtained specific volume anomaly profiles for all float positions, we bin-average these profiles over the $1^{\circ} \times 1^{\circ}$ grid (see Fig. $4 \mathrm{~b}$ ).

Fig. 4

Since the floats follow different pressure levels, velocity measurements from all the floats are projected onto the same pressure surface $\left(p_{\text {float }}=800 \mathrm{dbar}\right)$ using a simple correction from the thermal-wind relation. We choose the value of $800 \mathrm{dbar}$ since $60 \%$ of the float stations used are between 775 and 825 dbar. Next, we objectively map float velocities $\vec{V}_{\text {float }}$, binned on the same $1^{\circ} \times 1^{\circ}$ grid, multiplied by the Coriolis parameter $f$ to obtain streamfunction $\psi_{\text {float }}$ on the standard float level $p_{\text {float }}($ see Appendix A):

Fig. 5

$$
f \vec{V}_{\text {float }}=\vec{k} \times \nabla \psi_{\text {float }} .
$$

Note that we objectively map $f \vec{V}_{\text {float }}$ (instead of $\vec{V}_{\text {float }}$ ) because the procedure assumes zero divergence and it is $f \vec{V}_{\text {float }}$ that is in fact nondivergent under the geostrophic and hydrostatic assumptions (Gill, 1982; McDougall, 1989). Then the barotropic reference streamfunction $\psi_{b t}$ for the reference level $\left(p_{\text {ref }}=1000 \mathrm{dbar}\right)$ is obtained:

$$
\psi_{b t}\left(p_{\text {ref }}\right)=\psi_{\text {float }}\left(p_{\text {float }}\right)-\psi^{\prime}\left(p_{\text {float }}, p_{\text {ref }}\right)
$$

where $\psi^{\prime}$ is the geopotential anomaly at 800 dbar referenced to 1000 dbar and is given by

$$
\psi^{\prime}\left(p_{\text {float }}, p_{\text {ref }}\right)=\int_{p_{\text {float }}}^{p_{\text {ref }}} \delta_{f g} d p^{\prime},
$$

using the specific volume anomaly profiles $\left(\delta_{f g}\right)$ estimated at individual float positions with the float-GEM technique and binned on the same regular $1^{\circ} \times 1^{\circ}$ grid. The geopotential anomaly $\psi^{\prime}$ is similarly objectively mapped before being subtracted from $\psi_{\text {float }}$. It is consistent to obtain the 
barotropic reference streamfunction according to Equation 4, since both the baroclinic shear and the float absolute streamfunction on the float pressure surface are sampled at the same time and position. Figure 6 shows schematically the velocity structure calculations. Note that the term "barotropic reference" here refers to the flow at $p_{\text {ref }}=1000 \mathrm{dbar}$; it is neither the abyssal component, nor the vertically averaged component.

The barotropic mass transport for the top $1000 \mathrm{dbar}$ is then obtained from

$$
f \vec{M}_{1000}^{b t}=\int_{z(1000)}^{0} \rho(z) \vec{k} \times \nabla_{H} \psi_{b t} d z \approx \frac{10^{7}}{g} \vec{k} \times \nabla_{H} \psi_{b t}
$$

using the hydrostatic approximation $d p=-\rho g d z$ ( $z$ positive upwards) and considering the acceleration of gravity $g$ constant $\left(9.81 \mathrm{~m} \mathrm{~s}^{-2}\right)$.

The baroclinic mass transport for the top 1000 dbar is given by

$$
f \vec{M}_{1000}^{b c}=\int_{z(1000)}^{0} \vec{k} \times \nabla_{H} \psi_{b c} d z=\vec{k} \times \nabla_{H} \chi,
$$

where $\chi$ is the potential energy anomaly, also called the Fofonoff potential, referenced to 1000 dbar (Fofonoff, 1962) obtained using the float-GEM-estimated specific volume anomaly profiles $\left(\delta_{f g}\right)$ as follows:

$$
\chi=\frac{1}{g} \int_{0}^{1000 d b a r} p^{\prime} \delta_{f g} d p^{\prime}
$$

Similar to $\psi_{\text {float }}$ and $\psi^{\prime}, \chi$ is binned on the same regular $1^{\circ} \times 1^{\circ}$ grid and then objectively mapped. Note that $\chi$ is an exact streamfunction for $f \vec{M}_{1000}^{b c}$ under the geostrophic and hydrostatic approximations (Fofonoff, 1962).

Finally, the total mass transport for the top 1000 dbar can be obtained from the barotropic and baroclinic mass transports:

$$
f \vec{M}_{1000}^{\text {total }}=f \vec{M}_{1000}^{b t}+f \vec{M}_{1000}^{b c}
$$


or rather the exact streamfunction (in $\mathrm{kg} \mathrm{s}^{-2}$ ) for $f \vec{M}_{1000}^{\text {total }}$ is obtained as follows:

$$
\Phi=\frac{10^{7}}{g} \psi_{b t}+\chi
$$

Note, in contrast to Pérez-Brunius et al. (2004a,b), the mass transports $\vec{M}_{1000}^{\text {total }}, \vec{M}_{1000}^{b t}, \vec{M}_{1000}^{b c}$ are obtained by first calculating the horizontal gradients of their respective streamfunctions $\Phi$, $10^{7} g^{-1} \psi_{b t}, \chi$, and afterwards dividing by local $f$. Table 1 illustrates what happens if one divides the streamfunction by local $f$ prior to taking the horizontal gradient. The baroclinic mass transport across $36^{\circ} \mathrm{W}$ in $1^{\circ}$ latitude bands from $43^{\circ} \mathrm{S}$ to $25^{\circ} \mathrm{S}$ is obtained by taking the horizontal gradient either before or after dividing by $f\left(M\right.$ and $M^{\prime}$, respectively). The differences between $M$ and $M^{\prime}$ are significant and increase as latitude decreases, from $0.81 \times 10^{9} \mathrm{~kg} \mathrm{~s}^{-1}$ at $42-43^{\circ} \mathrm{S}$ to $3.26 \times 10^{9} \mathrm{~kg} \mathrm{~s}^{-1}$ at $25-26^{\circ} \mathrm{S}$. Note that integrating $M$ between $43^{\circ} \mathrm{S}$ and $25^{\circ} \mathrm{S}$ gives a mass transport of $15.51 \times 10^{9} \mathrm{~kg} \mathrm{~s}^{-1}$ whereas $M^{\prime}$ gives $50.38 \times 10^{9} \mathrm{~kg} \mathrm{~s}^{-1}$. Thus in our studied region, the exact formulation $(M)$ must be used. If desired, mass transport can be converted into volume transport and presented in $\mathrm{Sv}: 1.03 \times 10^{9} \mathrm{~kg} \mathrm{~s}^{-1}$ is roughly equivalent to $10^{6} \mathrm{~m}^{3} \mathrm{~s}^{-1}=1 \mathrm{~Sv}$ in the ocean. However, this conversion should be done only after the exact mass transports have been calculated. Details about the errors involved in the float-GEM technique can be found in Appendix B.

\section{Test of the Float-GEM Technique for the South Atlantic}

It is evident that the success of the float-GEM technique depends on how well profiles of temperature and specific volume anomaly are estimated from a single temperature and pressure measurement using the GEM fields. To test the technique, three small sections of WOCE hydrographic transects were used to simulate float data in the NW/SW subregions, i.e., cruise stations simulating float stations. The first section consisted of 25 stations of WOCE transect 
A17 (Mémery et al., 2000) within $46^{\circ}-36^{\circ} \mathrm{S}, 53^{\circ}-44^{\circ} \mathrm{W}$, the second section consisted of 19 stations of WOCE transect A23 (Heywood and King, 2002) within $46^{\circ}-33^{\circ} \mathrm{S}$, along $36^{\circ} \mathrm{W}$, and the third section consisted of 14 stations of WOCE transect HL (Campos et al. 1996) within $30^{\circ}-25^{\circ} \mathrm{S}, 44^{\circ}-38^{\circ} \mathrm{W}$ (see Fig. $4 \mathrm{a}$ for transect station locations). The float-GEM technique was then applied to recreate the profiles of temperature and specific volume anomaly for the WOCE transects from the GEM fields and compared with the real (measured) profiles.

The procedure is as follows: a float measurement of temperature at a particular station is simulated by obtaining the temperature ( $\left.T_{\text {cast }}\right)$ at the $800 \mathrm{dbar}$ level from each CTD cast, since $800 \mathrm{dbar}$ is our float pressure level. Then the simulated temperature profile is obtained by identifying the profile with the same ( $T_{\text {cast }}, 800 \mathrm{dbar}$ ) pair in the temperature GEM field, as shown in Figure 5. The corresponding geopotential anomaly value is also determined and used to look up the specific volume anomaly profile from its respective GEM field. Figure 7 shows the measured (solid line) and GEM-simulated (dashed line) profiles of (a) temperature and (b) specific volume anomaly for 6 representative stations in the A17 transect. The simulated profiles generally match the measured profiles well, except that small vertical scale variability is not reproduced. The greatest discrepancies are found within 100 dbar of the surface, where variability is not only related to meandering of baroclinic structure but also to interactions with the atmosphere.

Since the float-GEM technique uses specific volume anomaly profiles to calculate both the velocity shear between the float (800 dbar) and reference (1000 dbar) levels and also the integrated mass transport for the upper ocean, we can go a step further in checking the technique by calculating the geostrophic baroclinic velocity $(V)$ and baroclinic volume transport $(Q)$ across the section (in the 0-1000 dbar layer and referenced to the base of the layer) using both 
measured and GEM-generated specific volume anomaly profiles $\delta$ (see Appendix C). Figure 8 shows the geostrophic baroclinic velocity $(V)$ across the upper 1000 dbar of the A17 section, calculated from the measured specific volume anomaly profiles (top panel), from the GEMgenerated profiles (middle panel), and the difference between them (bottom panel). The total southeastward volume transport $(Q)$ for the A17 transect is $22 \mathrm{~Sv} \pm 2 \mathrm{~Sv}$ estimated from the float-GEM profiles and $19 \mathrm{~Sv}$ estimated from the actual CTD profiles. The float-GEM value is slightly larger than the real one. Here the $\pm 2 \mathrm{~Sv}$ represents error associated with the float-GEM technique, as described in Appendix C. The accuracy of the float-GEM estimates is $\pm 15 \%$ and the precision is $\pm 9 \%$ for A17 (for definitions see Section 4d in Pérez-Brunius et al., 2004a).

For transect A23, the directly calculated westward volume transport is $13 \mathrm{~Sv}$, the floatGEM estimated volume transport is $12.6 \mathrm{~Sv} \pm 0.5 \mathrm{~Sv}$ with an accuracy of $\pm 3 \%$ and a precision of $\pm 4 \%$. In this case, the error range includes the real transport and the float-GEM value is slightly smaller than the real one for A23. For the HL transect, total southwestward volume transport is 7.8 Sv \pm 0.6 Sv estimated from the float-GEM profiles and $6 \mathrm{~Sv}$ estimated from the actual CTD profiles. Recognizing the fact that the GEM-generated profiles are climatological, the float-GEM technique successfully estimates the baroclinic volume transport, giving confidence in using this method to calculate transports for the region covered by the floats in the South Atlantic.

\section{Results and Discussion}

The baroclinic, barotropic, and total mass transport streamfunctions are presented in Figure 9. Recall that the "barotropic" component is defined here as the transport due to the depthindependent reference flow at $1000 \mathrm{dbar}$ (see Fig. 6). Table 2 presents mass transport estimates for selected sections (A-K). The transects are chosen in locations where more float measurements are available. In regions where data availability is not a problem, they are chosen 
along latitude or longitude lines where there are estimates from previous studies for easy comparison. Mean errors in the baroclinic, barotropic, and total transport streamfunctions are $1.8,2.6$, and $3.4 \times 10^{5} \mathrm{~kg} \mathrm{~s}^{-2}$ respectively for the western basin and $1.5,3.2$, and $3.6 \times 10^{5} \mathrm{~kg} \mathrm{~s}^{-2}$ for the eastern basin (Appendix B). In Figure 10, we plot maps of volume transport per unit distance (corresponding to $1^{\circ}$ in this case).

Tab. 2

\section{a. Brazil Current}

The Brazil Current is the western boundary current of the South Atlantic subtropical gyre. When compared to its counterparts in the other oceans, such as the Kuroshio and the Gulf Stream, the Brazil Current is conspicuously weak. This is in part due to the fact that most of the transport of the SEC is lost to the equatorial undercurrents and to the northern hemisphere mainly through the North Brazil Current (Rodrigues et al., 2007).

The baroclinic transport for the Brazil Current is around $10 \mathrm{~Sv}: 10.7 \mathrm{~Sv}$ across $25^{\circ} \mathrm{S}$ (section $\mathrm{B}$ ), $11.2 \mathrm{~Sv}$ across $30^{\circ} \mathrm{S}$ (section $\mathrm{C}$ ), and $8.3 \mathrm{~Sv}$ across $35^{\circ} \mathrm{S}$ (section D). For the western basin, the mean error associated with the baroclinic transport is $\pm 2.9 \mathrm{~Sv}$ at $25^{\circ} \mathrm{S}, \pm 2.4 \mathrm{~Sv}$ at $30^{\circ} \mathrm{S}$, and $\pm 2.2 \mathrm{~Sv}$ at $35^{\circ} \mathrm{S}$. These errors represent approximately $27 \%$ of the baroclinic transport and are similar to the difference between the baroclinic transport estimates obtained from the GEM and real profiles for the HL transect (Section 3). Moreover, our results are in agreement with early studies because most of those studies used geostrophic velocities estimated from hydrographic data, and thus represent only the baroclinic component, varying from 4.1 to $11 \mathrm{~Sv}$ at $23^{\circ} \mathrm{S}$, from 7.5 to $14 \mathrm{~Sv}$ at $24^{\circ} \mathrm{S}$, and from 20 to $27 \mathrm{~Sv}$ at $28.5^{\circ} \mathrm{S}$ (Garfield, 1990 ; Peterson, 1992; Campos et al., 1995). This large variability in the estimates arises from different choices of reference level, as well as different times of sampling. 
When the first direct current measurements became available, the transport estimates revealed a much stronger flow in that region due to the contribution from the barotropic component (Garfield, 1990). Our results show this is indeed true only for the region south of $26^{\circ} \mathrm{S}$ due to the depth dependence of the bifurcation of the SEC. The SEC bifurcation occurs around $26^{\circ} \mathrm{S}-28^{\circ} \mathrm{S}$ at $1000 \mathrm{dbar}$ (Fig. 10b, the barotropic component refers to the flow at 1000 dbar), in agreement with Boebel et al (1999a), Wienders et al. (2000), and Rodrigues et al. (2007). The barotropic component (Figs. 9b and 10b) adds an extra 9.7 Sv to the Brazil Current across $30^{\circ} \mathrm{S}$ resulting in a total of $20.9 \mathrm{~Sv}$, and an extra $37.7 \mathrm{~Sv}$ across $35^{\circ} \mathrm{S}$ resulting in a total of $46 \mathrm{~Sv}$ (Figs. 9c and 10c, Tab. 2), but reduces the Brazil Current flow by $8 \mathrm{~Sv}$ across $25^{\circ} \mathrm{S}$. Garfield's (1990) direct measurements at $31^{\circ} \mathrm{S}$ show a Brazil Current total transport of $18 \mathrm{~Sv}$ across a $100 \mathrm{~km}$ transect, similar to the value found here (section $\mathrm{C}$ ). The errors associated with the total transport, $\pm 4.6 \mathrm{~Sv}$ at $30^{\circ} \mathrm{S}$ and $\pm 4 \mathrm{~Sv}$ at $35^{\circ} \mathrm{S}$, are larger than those related to the baroclinic transport. However, the transports themselves are also larger and thus the errors represent approximately $22 \%$ of the total transport at $30^{\circ} \mathrm{S}$ and $10 \%$ at $35^{\circ} \mathrm{S}$.

The total transport in the top 1000 dbar shows the SEC bifurcation at $24^{\circ} \mathrm{S}$ (Fig. 10c), which is the mean bifurcation latitude for the flow in the top 1000 dbar (Rodrigues et al., 2007). Across $20^{\circ} \mathrm{S}$ (section A), the net baroclinic and barotropic components of the Brazil Current/North Brazil Undercurrent system are both northward with a total transport of $20.7 \mathrm{~Sv}$. In the western South Atlantic, the predominant circulation south of $28^{\circ} \mathrm{S}$ is barotropic; north of $28^{\circ} \mathrm{S}$ the baroclinic component seems to dominate the circulation, except for the North Brazil Undercurrent area.

Fig. 9

b. Brazil-Malvinas Confluence Zone 
The warmer and saltier Brazil Current collides with the colder and fresher Malvinas Current around $38^{\circ} \mathrm{S}$ and both turn offshore (Stramma and Peterson, 1990). This region, called the Brazil-Malvinas Confluence, is characterized by fronts, meanders, and eddies. The Subtropical Front (STF) coincides with the southernmost edge of the Brazil Current, and the Subantarctic Front (SAF) with the northern edge of the Malvinas Current (Stramma and Peterson, 1990; Peterson and Stramma, 1991). The Malvinas Current is considered a branch of the Antarctic Circumpolar Current (ACC) that flows northeastward along the shelf break after passing through the Drake Passage (Peterson and Whitworth, 1989).

For the confluence region across $50^{\circ} \mathrm{W}$ between $42^{\circ} \mathrm{S}$ and $35^{\circ} \mathrm{S}$ (section E), we find an eastward baroclinic transport of $20.3 \mathrm{~Sv}$ in agreement with the Confluence Principal Investigators (1990) estimates (compare Fig. 9a with their Fig. 1). Even though the details of the confluence west of $53^{\circ} \mathrm{W}$ are not presented, it appears that $11.3 \mathrm{~Sv}$ come from the Brazil Current and the remaining $9 \mathrm{~Sv}$ from the Malvinas Current, similar to Figure 1 in Confluence Principal Investigators (1990).

When the barotropic component is included, the total transport map shows a swift eastern jet across $50^{\circ} \mathrm{W}$ with a transport of $45.8 \mathrm{~Sv}$ between $40^{\circ} \mathrm{S}$ and $38^{\circ} \mathrm{S}$ (in section E) and the existence of two anticyclonic recirculation cells in the southwest corner of the subtropical gyre north of $40^{\circ} \mathrm{S}$. The one centered at $48^{\circ} \mathrm{W}, 37^{\circ} \mathrm{S}$ recirculates $28.5 \mathrm{~Sv}$ and the other centered at $40^{\circ} \mathrm{W}, 38^{\circ} \mathrm{S}$ recirculates $13.9 \mathrm{~Sv}$. An additional recirculation flow of approximately $9 \mathrm{~Sv}$ encompasses both cells west of $32^{\circ} \mathrm{W}$ and south of $29^{\circ} \mathrm{S}$. Our results are corroborated by Stramma and Peterson (1990; their Figs. 2 and 8).

\section{c. South Atlantic Current}


The SAC is the eastward extension of the part of the Brazil Current that does not participate in a tight recirculation cell west of $30^{\circ} \mathrm{W}$; it also receives a contribution from the Malvinas Current in the confluence turbulent-mixing region. It is associated with the STF (Stramma and Peterson, 1990) and is considered the southern limb of the subtropical gyre (Stramma and England, 1999). As the SAC flows east, it approaches the Agulhas Rings region, where it interacts with rings pinched off westward from the Agulhas Current Retroflection. Part of the SAC then turns north to feed the Benguela Current, closing the South Atlantic subtropical gyre.

Fig. 10

The SAC has a transport of $50 \mathrm{~Sv}$ across $30^{\circ} \mathrm{W}$ (section F); $10.3 \mathrm{~Sv}$ of it comes from the Brazil Current and 39.7 Sv from the Malvinas/ACC system (Figs. 9c and 10c). Mean error for the $37^{\circ}-44^{\circ} \mathrm{S}$ latitude range is $\pm 3.7 \mathrm{~Sv}$. Stramma and Peterson (1990) estimate a transport of 30-37 Sv whereas Smythe-Wright et al. (1998) estimate a transport of $45.7 \mathrm{~Sv}$ for the SAC on the western side (Argentine Basin). However, both studies show an eastward weakening of the SAC with a transport of $14 \mathrm{~Sv}$ and $28.2 \mathrm{~Sv}$ on the eastern side (Cape Basin), respectively. Stramma and Peterson (1990) point out that the details involving this eastward weakening are unknown and speculate that the SAC transport should be less in the eastern basin because of the difference in the baroclinic structure, i.e., the deeper layers move in the same direction as the upper layer in the western basin, whereas in the eastern basin there is no significant zonal flow beneath the STF. Peterson and Stramma (1991) hypothesize that either the marked reduction occurs as the current flows over the mid-ocean ridge, or the flow gradually stems off to the interior of the subtropical gyre. Smythe-Wright et al. (1998) conclude that the decrease in the SAC is due to the recirculation of subtropical water west of $20^{\circ} \mathrm{W}$, rather than interaction with the midocean ridge. Moreover, they speculate that the Brazil Current probably turns northeast in 
the region around $40^{\circ} \mathrm{W}$, associated with the northeast turn of the Brazil Current Front. Reid (1994) also shows recirculation occurring around $20^{\circ} \mathrm{W}$ between $30^{\circ} \mathrm{S}$ and $40^{\circ} \mathrm{S}$.

At longitude $7^{\circ} \mathrm{W}$, the SAC seems to be split into two branches, one branch north of $38^{\circ} \mathrm{S}$ and the other branch south of $41^{\circ} \mathrm{S}$ (Figs. 9c and 10c). Across $0^{\circ}$, the northern branch of the SAC carries $19 \mathrm{~Sv}$ between $39^{\circ} \mathrm{S}$ and $36^{\circ} \mathrm{S}$ and the southern branch of the SAC carries $31 \mathrm{~Sv}$ between $47^{\circ} \mathrm{S}$ and $43^{\circ} \mathrm{S}$ (sections $\mathrm{G}$ and $\mathrm{H}$, respectively) leading to a total transport of $50 \mathrm{~Sv}$. The SAC has the same transport across $30^{\circ} \mathrm{W}$ and $0^{\circ}$, suggesting no recirculation east of $30^{\circ} \mathrm{W}$. (Mean error for this latitude range is $\pm 3.4 \mathrm{~Sv}$.) Earlier studies did not observe the SAC splitting because they only considered the baroclinic flow: the SAC splitting is not evident in the baroclinic component (Figs. 9a and 10a), i.e., the baroclinic part of the SAC consists of a single branch with a transport of $8.7 \mathrm{~Sv}$ across $0^{\circ}$ longitude between $39^{\circ} \mathrm{S}$ and $36^{\circ} \mathrm{S}$ (section G). Thus these studies concluded that there was an eastward weakening of the SAC due to recirculation within the gyre. Here we show that the apparent "eastward weakening" of the SAC around $38^{\circ} \mathrm{S}$ is due to the splitting of the current into two branches with most of its water flowing along the southern branch and eventually rejoining the ACC.

The northern branch of the SAC is associated with the STF, whereas the southern branch is related to the SAF (Belkin, 1993; Belkin and Gordon, 1996; Burls and Reason, 2006). More precisely, the SAC northern branch is located between the North and South STF (Smythe-Wright et al., 1998). Using surface drifters, altimeter data, and wind products, Niiler et al. (2003) generated a "hybrid" mean sea level data set from which a precise description of mesoscale structures of the global upper ocean emerged. Mean surface velocities obtained from the "hybrid" global mean sea level of the South Atlantic revealed two separate eastward jets similar to the results shown here (International Pacific Research Center, 2004; their Fig. 3). 
More recently, Richardson (2007) reported the split of the SAC into two branches using data from surface drifters and subsurface floats $(800 \mathrm{~m})$. Due to the sparseness of float data in the southwest corner of the eastern region, it is important that our results agree with Richardson (2007). The ALACE data used by Richardson (2007) provide measurements of the southern branch of the SAC in the southwest corner of our eastern domain (see his Fig. 3). The comparison of his Figure 13 (mean velocity vectors from subsurface floats 500-1100 m) with our Figure 10b (barotropic transport, related to the velocity field at 1000 dbar) shows good agreement with respect to the position and relative intensity of the two SAC branches. A highresolution numerical simulation by Biastoch et al. (2008) also reproduces the splitting of the SAC (see their Fig. 2a).

\section{d. Agulhas Current Retroflection}

The Agulhas Current is the western boundary current of the southern subtropical gyre of the Indian Ocean, lying along the southeastern continental shelf of Africa. It is mainly baroclinic, with more than $4 / 5$ of its transport in the upper $1000 \mathrm{~m}$ (Lutjeharms, 2006). When it reaches the southern tip of Africa, it proceeds southwest into the South Atlantic. Near $36^{\circ} \mathrm{S}$, the Agulhas Current retroflects back toward the Indian Ocean, enclosing Indian Ocean waters in its loop, but a portion of these waters leaks into the Atlantic.

The Agulhas Current Retroflection is well represented in our results (Fig. 9), reaching westward as far as $10^{\circ} \mathrm{E}$, and coincides with the Agulhas Front (Belkin and Gordon, 1996). It carries a transport of $48 \mathrm{~Sv}$ across $39^{\circ} \mathrm{S}$ between $10^{\circ} \mathrm{E}$ and $22^{\circ} \mathrm{E}$ (section I), of which $38 \mathrm{~Sv}$ retroflect east of $19^{\circ} \mathrm{E}$ : the remaining $10 \mathrm{~Sv}$ interact with waters brought by the SAC. Boebel and Barron (2003; their Fig. 3) have found similar features using altimeter derived geostrophic velocities. While Figure 9c properly represents temporal average transports, the process by 
which Indian Ocean water leaks into the South Atlantic, namely Agulhas Rings (Richardson, 2007), is highly transient. In the mean, about $8.5 \mathrm{~Sv}$ are injected from the retroflection region into the South Atlantic across $33^{\circ} \mathrm{S}$ between $12^{\circ} \mathrm{E}$ and $17^{\circ} \mathrm{E}$ (in section $\mathrm{J}$ ). This value is similar to those found in the literature (see review papers by de Ruijter et al., 1999 and Gordon, 2001).

Richardson (2007) observed an "Agulhas Extension" flowing westward from the Agulhas Current Retroflection as far as $5-25^{\circ} \mathrm{W}$ near $41^{\circ} \mathrm{S}$, which in our Figure 9c represents the region between the two SAC branches west of $10^{\circ} \mathrm{E}$. According to the author, this westward extension could be the cause of the SAC branching, with the northern branch being part of the South Atlantic subtropical gyre and the southern branch being the southern edge of a supergyre connecting the South Atlantic and South Indian oceans (de Ruijter, 1982; de Ruijter et al., 1999; Speich et al., 2007). Alternatively he suggests partial blocking by Gough Island and several seamounts $\left(10^{\circ} \mathrm{W}-1^{\circ} \mathrm{E}\right)$ may be responsible for the SAC branching.

\section{e. Cold-Water and Warm-Water Routes}

An important aspect of the global circulation, which has been the focus of great debate, is the source of the warm upper-layer water that flows northward through the Atlantic to compensate the colder southward flow of North Atlantic Deep Water as part of the global MOC. It is believed that about 15-20 Sv of cold deep water exits the Atlantic into the Southern Ocean, i.e., southward flow of the NADW (Bryden and Imawaki, 2001). But there are two main hypotheses for the source of the return flow waters into the Atlantic. One, called the warm-water route, consists of warmer, saltier waters from the Indian Ocean entering through the Agulhas Retroflection and shedding of Agulhas Rings in the Cape Basin (Gordon, 1986; Gordon et al., 1992; Lutjeharms, 1996; de Ruijter et al., 1999). The other, called the cold-water route, consists 
of colder, fresher waters from the Pacific Ocean brought by the ACC to the Atlantic, through the Drake Passage (Rintoul, 1991).

From the heat-balance standpoint, it has been argued that the warm-water route is the most important source of the return flow because Indian Ocean leakage water is warmer and saltier than its counterpart from the Pacific Ocean (Richardson et al., 2003), and because the Antarctic circumpolar region of the Southern Ocean cannot readily gain much heat from the atmosphere (Trenberth and Solomon, 1994). Several studies have shown that Agulhas leakage, in the form of Agulhas rings, is the major component of the upper-layer MOC (de Ruijter et al., 1999; Richardson et al. 2003; Lutjeharms, 2006; Richardson, 2007). Yet, there is no consensus on the transport in this leakage: mean Agulhas leakage (upper $\sim 1000 \mathrm{~m}$ ) into the South Atlantic is estimated to be in the range 4-10 Sv directly into the Benguela Current and 2-15 Sv through the intermittent shedding of Agulhas rings (Lutjeharms, 2006).

The complexity of the ocean circulation and sparseness of suitable direct measurements have been responsible hitherto for our lack of knowledge of the circulation patterns in the southeastern Atlantic. Here, we can follow transport isolines to determine the flow partition in terms of its origins because by definition there is no mass transport across the transport isolines in the mean. (Note, however, that at any specific time there is likely to be a net mass transport by the time-varying component of the flow across these isolines.) Using this procedure, here is what we find (see Fig. 11): of the $39.7 \mathrm{~Sv}$ of SAC transport that comes from the Malvinas Current/ACC system in the western basin and reaches the eastern basin at $0^{\circ}$ longitude, only 8.7 Sv flow with the northern branch; the remaining $31 \mathrm{~Sv}$ flow as the southern branch out of the South Atlantic rejoining the ACC directly (20.6 Sv) or interacting with the Agulhas Current Retroflection (10.4 Sv).

Fig. 11 
Of the $8.7 \mathrm{~Sv}$ that join the northern branch, $4 \mathrm{~Sv}$ flow southeast and interact with the Agulhas Current Retroflection. The remaining 4.7 Sv of Malvinas Current/ACC origin and the 10.3 Sv from the Brazil Current (a total of $15 \mathrm{~Sv}$ across $33^{\circ} \mathrm{S}$ between $8^{\circ} \mathrm{E}$ and $12^{\circ} \mathrm{E}$, in section $\mathrm{J}$ ) stays in the South Atlantic forming the Benguela Current, together with $8.5 \mathrm{~Sv}$ from the Agulhas leakage (across $33^{\circ} \mathrm{S}$ between $12^{\circ} \mathrm{E}$ and $17^{\circ} \mathrm{E}$, in section $\mathrm{J}$ ). Thus, across $33^{\circ} \mathrm{S}$ the total northward transport is $23.5 \mathrm{~Sv}$. The Benguela Current carries $15 \mathrm{~Sv}$ westward across $3^{\circ} \mathrm{E}$ between $32^{\circ} \mathrm{S}$ and $27^{\circ} \mathrm{S}$ (section K). Note that this estimate of the Benguela Current transport is probably not its total westward transport across $3^{\circ} \mathrm{E}$, since our maps (i.e., float measurements) do not extend north of $27^{\circ} \mathrm{S}$.

Although, in a mean transport map, the rings themselves are not captured, the transports associated with them are included. Mean total mass transports of the cold- and warm-water routes are comparable in the upper 1000 dbar. From the aforementioned discussion, the coldwater route carries directly $4.7 \mathrm{~Sv}\left(8^{\circ} \mathrm{E}-12^{\circ} \mathrm{E}\right.$, in section $\mathrm{J}$ transport less $10.3 \mathrm{~Sv}$ from the Brazil Current), whereas the warm-water route directly carries $8.5 \mathrm{~Sv}\left(12^{\circ} \mathrm{E}-17^{\circ} \mathrm{E}\right.$, in section $\left.\mathrm{J}\right)$. Moreover, waters from both routes interact strongly in Cape Basin: 4 Sv from the northern SAC branch and 10.4 Sv from the southern SAC branch (both of Malvinas Current/ACC system origin) interacts with $10 \mathrm{~Sv}$ from the Agulhas Current Retroflection (gray shaded area in Fig. 11). Combining these estimates, there are, entering Cape Basin, $4.7+4+10.4=19.1 \mathrm{~Sv}$ of water from the Pacific and $8.5+10=18.5 \mathrm{~Sv}$ from the Indian Ocean.

These results imply that 50\% (20.6 Sv) of the water from the Pacific rejoins the ACC immediately and only $12 \%$ (4.7 Sv) directly feeds the Benguela Current. Previous studies have shown that very little of the water exported to the Atlantic follows the direct cold-water route from Drake Passage. For instance, Friocourt et al. (2005) have found from numerical simulations 
that $4-8 \%$ of water from the Drake Passage is exported to the equator in the Atlantic (1-2 Sv of a total of $23 \mathrm{~Sv}$ ). But previous studies appear to have underestimated the importance of the coldwater route. Vigorous stirring in the "Cape Cauldron" (Boebel et al., 2003) mixes cold water from the Pacific with water in Agulhas rings so these rings effectively carry water originating from both routes.

\section{Conclusions}

This study has used the float-GEM technique to obtain the structure of mean flow in the upper 1000 dbar of the subtropical South Atlantic gyre within the Argentine and Cape Basins. It is novel in that it 1) develops a more exact method for the GEM-determination of mass transport and applies it to quasi-isobaric float data, and 2) uses the method throughout the region to determine baroclinic and barotropic - and hence total-mean transports in this top $1000 \mathrm{dbar}$ layer by a uniform procedure.

Significant differences between the baroclinic and total mass transports presented in this study highlight the importance of having direct measurements of the flow in the South Atlantic subtropical gyre, since the streamlines inferred from hydrographic data alone (i.e., baroclinic streamlines) show only a small portion of the total flow in many of these areas. The barotropic component, comprising recirculation cells in the west and, in the east, splitting of the SAC and extension of the Agulhas Current Retroflection, greatly changes the total circulation quantitatively and qualitatively from that of the baroclinic circulation alone.

The baroclinic transport map suggests a weak and broad eastward flow of $20.3 \mathrm{~Sv}$ in the confluence region across $50^{\circ} \mathrm{W}$, with $11.3 \mathrm{~Sv}$ from the Brazil Current and $9 \mathrm{~Sv}$ from the Malvinas Current, and 17.6 Sv across $30^{\circ} \mathrm{W}$. In contrast, the total transport shows a well-defined and strong eastward SAC flow with a transport of $50 \mathrm{~Sv}$ in the western basin across $30^{\circ} \mathrm{W}, 39.7$ 
Sv coming from the Malvinas Current/ACC system and only $10.3 \mathrm{~Sv}$ from the Brazil Current. The Brazil Current carries a southward transport of $20.9 \mathrm{~Sv}$ at $30^{\circ} \mathrm{S}$ and $46 \mathrm{~Sv}$ at $35^{\circ} \mathrm{S}$. The results shown here reveal the presence of two strong anticyclonic cells: one centered at $48^{\circ} \mathrm{W}$, $37^{\circ} \mathrm{S}$ recirculates $28.5 \mathrm{~Sv}$ and the other centered at $40^{\circ} \mathrm{W}, 38^{\circ} \mathrm{S}$ recirculates $13.9 \mathrm{~Sv}$.

In the eastern basin at $0^{\circ}$ longitude, the baroclinic component of the SAC consists of a single, weak eastward jet of approximately $8.7 \mathrm{~Sv}$. The total transport map reveals a completely different picture. The SAC splits into a northern branch carrying $19 \mathrm{~Sv}$ and a southern branch carrying $31 \mathrm{~Sv}$, i.e. a total of $50 \mathrm{~Sv}$. The eastward weakening of the SAC transport previously reported is due to the inability of earlier works to identify the SAC southern branch from baroclinic estimates. Of the $39.7 \mathrm{~Sv}$ of $\mathrm{SAC}$ transport that comes from the Malvinas Current/ACC system in the western basin and reaches the eastern basin at $0^{\circ}$ longitude, $4.7 \mathrm{~Sv}$ stay in the South Atlantic together with $10.3 \mathrm{~Sv}$ from the Brazil Current, forming the Benguela Current and recirculating within the subtropical gyre. Most of the remaining $31 \mathrm{~Sv}$ flows out of the South Atlantic rejoining the ACC directly or through the Agulhas Current Retroflection. The retroflection is well captured in the mean transport map, reaching as far as $10^{\circ} \mathrm{E}$ with a transport of $48 \mathrm{~Sv}$.

More importantly, the results discussed here reveal that the cold-water route has a direct transport of 4.7 Sv and the warm-water route a direct transport of $8.5 \mathrm{~Sv}$. The remaining $14.4 \mathrm{~Sv}$ of cold water from the Pacific interacts in Cape Basin with $10 \mathrm{~Sv}$ of warm waters from the Indian Ocean. The cold-water route should be seen as an extended stream of the ACC flowing northeastward in the western basin, which then turns eastward along with the SAC north of $45^{\circ} \mathrm{S}$. Along its way across the South Atlantic, cold waters from the Pacific exchange heat by lateral mixing with warm waters from the Brazil Current and by air-sea fluxes, ultimately interacting 
with warmer waters from the Indian Ocean brought into the Cape Basin by the Agulhas Current Retroflection and rings (warm-water route).

Further investigation is necessary to determine how much heat is exchanged. For instance, it is possible to estimate the heat transport of the SAC and determine the contributions from lateral mixing and air-sea fluxes using analyses similar to those presented by Pérez-Brunius et al. (2004b) for the North Atlantic Current-Subpolar Front system. It is also important to know the effects of a poleward shift of the Southern Hemisphere westerlies on both routes. Biastoch et al. (2009) have established that such a wind shift causes an increase in the Agulhas leakage. In addition, we need to determine the impact on the cold-water route of the concurrent poleward shift of the subtropical gyre and the intensification of the ACC.

Finally, the temporal variability of the MOC has a vital role on the world's climate over decadal timescales. Recently, Biastoch et al. (2008) have shown that part of the MOC variability originates in Agulhas leakage dynamics. This finding is based on modeling work; we do not yet have enough data to establish the decadal variability of the MOC. Although, several programs have been launched recently to monitor MOC variability in different parts of the world oceans, knowledge of the mean state of previous periods is valuable for comparison. This study has established the mean state of the subtropical gyre and the mean contributions of the cold and warm routes for 1992-2001 period.

Acknowledgments. The authors thank Byron Willeford for helping with the construction of the GEM fields, Paula Pérez-Brunius for developing the float-GEM technique, Thomas Rossby for valuable discussion, and Olaf Boebel for providing the RAFOS float data. This paper has benefited considerably from the helpful advice of reviewers. RRR especially thanks the National 
Council for Research and Scientific Development $(\underline{\mathrm{CNPq}})$ and the Ministry of Science and Technology of Brazil for support (Grant 200777/98-0). 


\section{APPENDIX A}

\section{Optimal Interpolation}

After binning each float-GEM derived field $\varphi\left(f \vec{V}_{f l o u t}, \psi^{\prime}, \chi\right)$ on the $1^{\circ} \times 1^{\circ}$ grid shown in Figure 4b, a two-pass multivariate optimal interpolation (OI), as described by Watts et al. (2001), is used to map the field throughout the full grid. Subsequent to removing the means, broad-scale background fields $\varphi_{\mathrm{bg}}$ are obtained by carrying out a preliminary pass of the OI with a correlation length scale of $200 \mathrm{~km}$. Then to resolve smaller scales, a second pass of the OI, with correlation length scale of $100 \mathrm{~km}$, is applied to residual fields $\varphi_{\text {res }}$ obtained by subtracting the background fields from the observations. According to Chelton et al. (1998), the first baroclinic radius of deformation for our area of study is $25-50 \mathrm{~km}$, and according to Stammer (1997) the zero crossing of the covariance functions corresponding to this radius of deformation is $\sim 100 \mathrm{~km}$.

The final fields are obtained by adding the means and background fields to the interpolated residual fields. Since the OI technique is a linear estimator, we can use the same input data to obtain an estimate of a linear operator on $\varphi$ by applying the operator to the covariance function, using the same input data (Bretherton et al., 1976). In this case, the geostrophic constraint is imposed via the covariance functions to obtain the absolute streamfunction from the absolute velocity data (see Watts et al., 2001 for more details), but multiplied by $f$ since the OI method assumes non-divergence of the velocity field (hence the need to use $f \vec{V}_{f l o a t}$ instead of $\vec{V}_{f l o a t}$ ). 


\section{APPENDIX B}

\section{Streamfunction Errors}

Errors in the streamfunctions calculated in Section $2 \mathrm{~b}$ are obtained as follows:

$$
\begin{gathered}
E_{\vec{M}_{\text {total }}}=\sqrt{E_{\vec{M}_{b t}}^{2}+E_{\vec{M}_{b c}}^{2}}, \\
E_{\vec{M}_{b t}}=\frac{10^{7}}{g} E_{\psi_{b t}}=\frac{10^{7}}{g} \sqrt{E_{\psi_{f l o a t}}^{2}+E_{\psi^{\prime}}^{2}}, \\
E_{\vec{M}_{b c}}=E_{\chi} .
\end{gathered}
$$

$E$ denotes the total error involved in the estimate of the variable in question $\left(\psi_{f l o a t}, \psi^{\prime}, \chi\right)$ and consists of two components, one associated with the float-GEM technique $\varepsilon_{f g}$ and the other associated with the binning of the variable $\varepsilon_{b}$, so that

$$
E=\sqrt{\varepsilon_{f g}^{2}+\varepsilon_{b}^{2}} .
$$

For the case of both $\psi^{\prime}$ and $\chi, \varepsilon_{f g}$ is obtained from the uncertainty associated with the estimated profile of specific volume anomaly at each float data point, given the uncertainties in the hydrographic and float data:

$$
\varepsilon_{f g}(p, \vec{X})=\sqrt{\varepsilon_{G E M}^{2}(p, \vec{X})+\varepsilon_{p f}^{2}(p, \vec{X})+\varepsilon_{T f}^{2}(p, \vec{X})} .
$$

The first error term $\varepsilon_{G E M}$ is the GEM field mean-square error and is determined as the rms difference between the values in a GEM bin $\left(0.2 \mathrm{~m}^{2} \mathrm{~s}^{-2}\right.$ by $\left.25 \mathrm{dbar}\right)$ and all the hydrographic measurements that fall within that bin:

$$
\varepsilon_{G E M}^{2}=\left\langle\left(\delta_{G E M}-\delta_{\text {hydrocast }}\right)^{2}\right\rangle
$$

The second error term is a result of error in the estimate of $\phi_{\text {float }}$ (i.e., $\phi_{\text {float }} \pm \varepsilon_{\phi f l o a t}$ ) from the temperature GEM field due to the error in the pressure measured by the float ( $p_{\text {float }} \pm \varepsilon_{p f l o a t}$, with $\varepsilon_{\text {pfloat }}=10 \mathrm{dbar}$ ). In other words, the pressure error leads to an uncertainty in the geostrophic 
streamfunction values $\left(\varepsilon_{\phi f l o a t}\right)$, which results in uncertainty in determining the profile of specific volume anomaly $\varepsilon_{p f}$. This error is given by the larger of the two differences between the profile associated with $\phi_{\text {float }}$ and the profiles associated with $\phi_{\text {float }} \pm \varepsilon_{\phi f l o a t}$ from the GEM field:

$$
\begin{array}{r}
\varepsilon_{p f}=\max \left[\left|\delta_{G E M}\left(p, \phi_{\text {float }}\right)-\delta_{G E M}\left(p, \phi_{\text {float }}+\varepsilon_{\phi_{\text {float }}}\right)\right|\right. \\
\left.\left|\delta_{G E M}\left(p, \phi_{\text {float }}\right)-\delta_{G E M}\left(p, \phi_{\text {float }}-\varepsilon_{\phi_{\text {float }}}\right)\right|\right] .
\end{array}
$$

Likewise, the third error term, an uncertainty $\varepsilon_{T f}$ in determining the specific volume anomaly profiles, arises from the uncertainty in the temperature measured by the float $\left(T_{\text {float }} \pm \varepsilon_{\text {Tfloat }}\right.$, with $\left.\varepsilon_{\text {Tfloat }}=0.1^{\circ} \mathrm{C}\right)$ (Figure 5). Pressure and temperature measurements of RAFOS floats have accuracies of $10 \mathrm{dbar}$ and $0.1^{\circ} \mathrm{C}$ and MARVOR floats have accuracies of $10 \mathrm{dbar}$ and $0.03^{\circ} \mathrm{C}$, respectively (Rossby et al., 1986; Boebel et al., 1995; Ollitrault et al., 1995). Thus the float-GEM errors associated with $\psi^{\prime}$ and $\chi$ are estimated from $\varepsilon_{f g}$ profiles using Equations 5 and 8, respectively. (Note that the three error terms in Equation B5 are assumed independent.)

The error $\varepsilon_{b}$ involved in the binning of the fields $\psi^{\prime}$ and $\chi$ is simply the standard error of the mean value of the variables $\psi^{\prime}$ and $\chi$ in the bin in question, given by

$$
\varepsilon_{b}=\frac{\sigma}{\sqrt{N}}
$$

where $\sigma$ is the standard deviation of the float-GEM data in the bin, and $N$ is the number of observations in the bin. For those $4 \%$ of the bins which have $N=1, \varepsilon_{b}$ was determined by interpolation from surrounding bins.

For the case of $\psi_{f l o a t}$, the total error in Equation B2 is given by

$$
E_{\psi_{\text {float }}}=\frac{E_{f U_{\text {float }} \Delta y}+E_{f V_{\text {float }} \Delta x}}{2},
$$


where $f$ is local Coriolis parameter, $\Delta x$ and $\Delta y$ are the distances in $\mathrm{km}$ corresponding to $1^{\circ}$ of longitude and latitude, respectively. $E_{f U_{f l o a t} \Delta y}$ and $E_{f V_{f o a t} \Delta x}$ are respectively the total errors associated with the zonal $\left(U_{\text {float }}\right)$ and meridional $\left(V_{\text {float }}\right)$ velocities measured by the floats. The float-GEM component $\varepsilon_{f g}$ of their total error is obtained by considering a $2 \mathrm{~km}$ error in the float positioning for the RAFOS floats (Boebel et al., 1997; Boebel et al., 1999a, 2000); 2 km per day gives an error of $2.3 \mathrm{~cm} \mathrm{~s}^{-1}$. The error in estimating the float velocity for the MARVOR floats is $1 \mathrm{~cm} \mathrm{~s}^{-1}$, according to Ollitrault et al. (1995). The binning component of their total error is given by Equation B8. Note that in determining the binning error, we use a temporal decorrelation scale of 10 days for the intermediate layer of the South Atlantic (Boebel et al., 1999c). In other words, we consider only float measurements from the same bin that are at least 10 days apart, to ensure statistical independence.

This formulation assumes the errors in the barotropic and baroclinic components of the streamfunctions are uncorrelated. Tables B1 and B2 show the mean values of the errors associated with both float-GEM estimation and binning of the variables for the western and eastern basin regions, respectively. Tabs. B1, B2 


\section{APPENDIX C}

\section{Volume Transport Estimate and Errors}

The volume transport relative to $1000 \mathrm{dbar}(Q)$ is estimated as follows:

$$
Q=\int_{0}^{L} \int_{0}^{1000 d b a r} V(p, \vec{X}) d p d x
$$

where

$$
\begin{aligned}
& V(p, \vec{X})=\frac{1}{f} \frac{\partial \Psi(p, \vec{X})}{\partial x} \\
& \Psi(p, \vec{X})=\int_{p}^{1000 d b a r} \delta\left(p^{\prime}, \vec{X}\right) d p^{\prime}
\end{aligned}
$$

$x$ is the distance along the transect, $L$ transect length, $\vec{X}$ position vector, $f$ local Coriolis parameter, $V$ baroclinic velocity and $\Psi$ geopotential anomaly (both referenced to 1000 dbar).

The errors $\pm \varepsilon Q$ associated with the volume transports estimated with the float-GEM technique are calculated as

$$
(\varepsilon Q)^{2}=\sum_{i}\left[\varepsilon Q_{0}(i) \Delta x(i)\right]^{2}
$$

where

$$
\begin{gathered}
{\left[\varepsilon Q_{0}(i)\right]^{2}=\sum_{k}[\varepsilon V(k, i) \Delta p(k)]^{2},} \\
\varepsilon V(k, i)=\frac{1}{f} \frac{\varepsilon \Delta \Psi(k, i)}{\Delta x(i)}, \\
{[\varepsilon \Delta \Psi(k, i)]^{2}=\left[\varepsilon \Psi\left(k, i+\frac{1}{2}\right)\right]^{2}+\left[\varepsilon \Psi\left(k, i-\frac{1}{2}\right)\right]^{2},}
\end{gathered}
$$

the indices $(k, i)$ designate vertical and horizontal bins, respectively and $\varepsilon \Psi$ is the float-GEM error associated with $\Psi$ given by Equation B5. 


\section{REFERENCES}

Belkin, I. M. 1993. Frontal Structure of the South Atlantic, in Pelagic Ecosystems of the Southern Ocean, N. M. Voronina, ed., Nauka, 40-53.

Belkin, I. M. and A.L. Gordon. 1996. Southern Ocean fronts from the Greenwich meridian to Tasmania. J. Geophys. Res., 101, 3675-3696.

Biastoch, A., C. W. Böning and J.R.E. Lutjeharms. 2008. Agulhas leakage dynamics affects decadal variability in Atlantic overturning circulation. Nature, 456, 489-492.

Biastoch, A., C. W. Böning, F. U. Schwarzkopf and J. R. E. Lutjeharms. 2009. Increase in Agulhas leakage due to poleward shift of Southern Hemisphere westerlies. Nature, 462, 495498.

Boebel, O., S. Anderson-Fontana, C. Schmid, I. Ansorge, P. Lazarevich, J. Lutjeharms, M.D. Prater, T. Rossby and W. Zenk. 2000. KAPEX RAFOS Float Data Report 1997-1999. Part A: The Agulhas- and South Atlantic Current Components. Graduate School of Oceanography Technical Report 2000-2, 194 pp.

Boebel, O. and C. Barron. 2003. A comparison of in-situ float velocities with altimeter derived geostrophic velocities. Deep-Sea Res. II, 50, 119-139.

Boebel, O., R. E. Davis, M. Ollitrault, R. G. Peterson, P. L. Richardson, C. Schmid and W. Zenk. 1999a. The intermediate depth circulation of the western South Atlantic. Geophys. Res. Lett., $26,3329-3332$.

Boebel, O., J. Lutjeharms, C. Schmid, W. Zenk, T. Rossby and C. Barron. 2003. The Cape Cauldron: a regime of turbulent inter-ocean exchange. Deep-Sea Res. II, 50, 57-86.

Boebel, O., C. Schmid, G. Podesta and W. Zenk. 1999b. Intermediate water in the BrazilMalvinas Confluence Zone: a Lagrangian view. J. Geophys. Res., 104, 21063-21082. 
Boebel, O., C. Schmid and W. Zenk. 1997. Flow and recirculation of Antarctic Intermediate Water across the Rio Grande Rise. J. Geophys. Res., 102, 20967-20986.

Boebel, O., C. Schmid and W. Zenk. 1999c. Kinematic elements of Antarctic Intermediate Water in the western South Atlantic. Deep-Sea Res. II, 46, 355-392.

Boebel, O., K. L. Schultz-Tokos and W. Zenk. 1995. Calculation of salinity from neutrally buoyant RAFOS floats. J. Atmos. Oceanic Technol., 12, 923-934.

Bretherton, F. P., R. E. Davis and C.B. Fandry. 1976. A technique for objective analysis and design of oceanographic experiments applied to MODE-73. Deep-Sea Res., 23, 559-582.

Bryden, H. L. and S. Imawaki. 2001. Ocean Heat Transport, in Ocean Circulation and Climate: Observing and Modelling the Global Ocean, G. Siedler, J. Church and J. Gould, eds., Academic Press, 455-474.

Burls, N. J. and C. J. C. Reason. 2006. Sea surface temperature fronts in the midlatitude South Atlantic revealed by using microwave satellite data. J. Geophys. Res., 111, C08001, doi:10.1029/2005JC003133.

Campos, E. J. D., J. E. Gonçalves and Y. Ikeda. 1995. Water mass characteristics and geostrophic circulation in the South Brazil Bight: Summer of 1991. J. Geophys. Res., 100, $18537-18550$.

Campos, E. J. D., Y. Ikeda, B. M. Castro, S. A. Gaeta, J. A. Lorenzzetti and M.R. Stevenson. 1996. Experiment Studies Circulation in the Western South Atlantic. EOS Transactions, Am. Geophys. Union, 77, 253-259.

Chelton, D. B., R. A. DeSzoeke, M. G. Schlax, K. El Naggar and N. Siwertz. 1998. Geographical variability of the first baroclinic Rossby radius of deformation. J. Phys. Oceanogr., 28, $433-460$. 
Confluence Principal Investigators. 1990. Confluence 1988-1990: An intensive study of the southwestern Atlantic. EOS, 71, 431-437.

Curry, R. G. 1996. Hydrobase: A Database of Hydrographic Stations and Tools for Climatological Analysis. Woods Hole Oceanographic Institute Tech. Rep., WHOI-96-01, 50 pp.

de Ruijter, W. P. M. 1982. Asymptotic analysis of the Agulhas and Brazil Current systems. J. Phys. Oceanogr., 12, 361-373.

de Ruijter, W. P. M., A. Biastoch, S. S. Drijfhout, J. R. E. Lutjeharms, R. P. Matano, T. Pichevin, P. J. van Leeuwen and W. Weijer. 1999. Indian-Atlantic interocean exchange: dynamics, estimation and impact. J. Geophys. Res., 104, 20885-20910.

Fofonoff, N. P. 1962. Physical Properties of Sea Water, in The Sea. M. N. Hill, ed., Wiley, 3-30.

Friocourt, Y., S. Drijfhout, B. Blanke and S. Speich. 2005. Water mass export from Drake Passage to the Atlantic, Indian, and Pacific oceans: a Lagrangian model analysis. J. Phys. Oceanogr., 35, 1206-1222.

Garfield III, N. 1990. The Brazil Current at subtropical latitudes. Doctoral Dissertation, University of Rhode Island, Narragansett, $132 \mathrm{pp}$.

Gill, A. E. 1982. Atmosphere-Ocean Dynamics. Academic Press, 662 pp.

Gordon, A. L. 1985. Indian-Atlantic transfer of thermocline water at the Agulhas Retroflection. Science, 227, 1030-1033.

Gordon, A. L. 1986. Interocean exchange of thermocline water. J. Geophys. Res., 91, $5037-5046$. 
Gordon, A. L. 2001. Interocean Exchange in Ocean Circulation and Climate: Observing and Modelling the Global Ocean, G. Siedler, J. Church and J. Gould, eds., Academic Press, $303-314$.

Gordon, A. L., R. F. Weiss, W. J. Smethie, M. J. Warner. 1992. Thermocline and intermediate water communication between the South Atlantic and Indian Oceans. J. Geophys. Res., 97, $7223-7240$.

Heywood, K. J. and B. A. King. 2002. Water masses and baroclinic transports in the South Atlantic and Southern oceans. J. Mar. Res., 60, 639-676.

International Pacific Research Center, 2004. The global ocean: a 10-year portrait of the nearsurface circulation. IPRC Climate Newsletter, $4 \quad$ (1), 4-5. http://iprc.soest.hawaii.edu/publications/publications.html.

Lutjeharms, J. R. E. 2006. The Agulhas Current. Springer, 329 pp.

Lutjeharms, J. R. E. 1996. The exchange of water between the South Indian and South Atlantic

Oceans, in The South Atlantic: Present and Past Circulation, G. Wefer, W. H. Berger, G. Siedler and D. Webb, eds., Springer, 125-162.

McDougall, T. J. 1989. Streamfunctions for the lateral velocity vector in a compressible ocean. J. Mar. Res., 47, 267-284.

Meinen, C. S. and D. R. Watts. 2000. Vertical structure and transport on a transect across the North Atlantic Current near $42^{\circ} \mathrm{N}$ : Time series and mean. J. Geophys. Res., 105, 21869-21891.

Mémery, L., M. Arhan, X. A. Alvarez-Salgado, M-J. Messias, H. Mercier, C. G. Castro and A. F. Rios. 2000. The water masses along the western boundary of the South and Equatorial Atlantic. Prog. Oceanogr., 47, 69-98. 
Niiler, P. P., N. A. Maximenko and J. C. McWilliams. 2003. Dynamically balanced absolute sea level of the global ocean derived from near-surface velocity observations. Geophys. Res. Lett., 30, 2164, doi:10.1029/2003 GL018628.

Olbers, D., V. V. Gouretski, G. Seiß and J. Schröter. 1992. Hydrographic Atlas of the Southern Ocean. Alfred Wegener Institute for Polar and Marine Research, Bremerhaven, Germany \& Arctic and Antarctic Research Institute, St. Petersburg, Russia. http://www.pangaea.de.

Ollitrault, M. 1999. MAVOR floats reveal intermediate circulation in the western equatorial and tropical South Atlantic $\left(30^{\circ} \mathrm{S}\right.$ to $\left.50^{\circ} \mathrm{S}\right)$. International WOCE Newsletter, 34, 7-10.

Ollitrault, M., G. Loaec and C. Dumortier. 1994. MARVOR: A multi-cycle RAFOS float. Sea Technol., 35, 39-44.

Ollitrault, M., Y. Auffret, N. Cortes, C. Hemon, P. Jegou, S. Le Reste, G. Loaec and J. P. Rannou. 1995. The Samba Experiment. Volume 1: Samba 1 Lagrangian and CTD data (February 1994-August 1995). Technical Report Repères Océan, 12, 1-488.

Pérez-Brunius, P., T. Rossby and D. R. Watts. 2004a. A method for obtaining the mean transports of ocean currents by combining isopycnal float data with historical hydrography. J. Atmos. Oceanic Technol., 21, 298-316.

Pérez-Brunius, P., T. Rossby and D. R. Watts. 2004b. Absolute transports of mass and temperature for the North Atlantic Current- Subpolar Front system. J. Phys. Oceanogr., 34, $1870-1883$.

Peterson, R. G. 1992. The boundary currents in the western Argentine Basin. Deep-Sea Res. I, $39,623-644$.

Peterson, R. G. and L. Stramma. 1991. Upper-level circulation in the South Atlantic Ocean. Prog. Oceanogr., 26, 1-73. 
Peterson, R. G. and T. Whitworth III. 1989. The subantarctic and polar fronts in relation to deep water masses through the southwestern Atlantic. J. Geophys. Res., 94, 10817-10838.

Reid, J. L. 1994. On the total geostrophic circulation of the North Atlantic Ocean: Flow patterns, tracers, and transports. Prog. Oceanogr., 33, 1-92.

Richardson, P. L. 2007. Agulhas leakage into the Atlantic estimated with subsurface floats and surface drifters. Deep-Sea Res. I, 54, 1361-1389.

Richardson, P. L., J. E. R. Lutjeharms and O. Boebel. 2003. Introduction to the "Inter-ocean exchange around southern Africa". Deep-Sea Res. II, 50, 1-12.

Rintoul, S. R. 1991. South Atlantic interbasin exchange. J. Geophys. Res., 96, 2675-2692.

Rodrigues, R. R. 2004. An observational and numerical study of the South Atlantic Circulation. Doctoral Dissertation, University of Rhode Island, Narragansett, 175 pp.

Rodrigues, R. R., L. Rothstein and M. Wimbush. 2007. Seasonal variability of the South Equatorial Current bifurcation in the Atlantic Ocean: A numerical study. J. Phys. Oceanogr., $37,16-30$.

Rossby, T., D. Dorson and J. Fontaine. 1986. The RAFOS System. J. Atmos. Oceanic Technol., $3,672-679$.

Smythe-Wright, D., P. Chapman, C. Duncombe Rae, L. V. Shannon and S. M. Boswell. 1998. Characteristics of the South Atlantic subtropical frontal zone between $15^{\circ} \mathrm{W}$ and $5^{\circ} \mathrm{E}$. DeepSea Res. I, 45, 167-192.

Speich, S., B. Blanke and G. Madec. 2001. Warm and cold water routes of an O.G.C.M. thermohaline conveyor belt. Geophys. Res. Lett., 28, 311-314. 
Speich, S., B. Blanke and W. Cai. 2007. Atlantic meridional overturning circulation and the Southern Hemisphere supergyre. Geophys. Res. Lett., 34, L23614, doi:10.1029/2007GL031583.

Stammer, D. 1997. Global characteristics of ocean variability estimated from regional TOPEX/POSEIDON altimeter measurements. J. Phys. Oceanogr., 27, 1743-1769.

Stramma, L. and M. England. 1999. On the water masses and mean circulation of the South Atlantic Ocean. J. Geophys. Res., 104, 20863-20883.

Stramma, L. and R. G. Peterson. 1990. The South Atlantic Current. J. Phys. Oceanogr., 20, $846-859$.

Sun, C. and D. R. Watts. 2001. A circumpolar gravest empirical mode for the Southern Ocean hydrography. J. Geophys. Res., 106, 2833-2855.

Trenberth, K. E. and A. Solomon. 1994. The global heat balance: Heat transports in the atmosphere and ocean. Climate Dyn., 10, 107-134.

Watts, D. R., X. Qian and K. L. Tracey. 2001. Mapping abyssal current and pressure fields under the meandering Gulf Stream. J. Atmos. Oceanic Technol., 18, 1052-1067.

Wienders, N., M. Arhan and H. Mercier. 2000. Circulation at the western boundary of the South and Equatorial Atlantic: Exchanges with the ocean interior. J. Mar. Res., 58, 1007-1039. 


\section{LIST OF FIGURE CAPTIONS}

Figure 1. Subregions selected for the construction of the GEM fields. Dots represent the CTD and bottle cast locations used from HydroBase and AWI data sets.

Figure 2. The final smooth GEM fields of temperature (top left) and specific volume anomaly (top right) for the SW region. Dots at 900 dbar and 3800 dbar indicate station locations in streamfunction space. Bottom six panels show the data and their smoothing spline fits at 200, 400, and $800 \mathrm{dbar}$ for temperature (left) and specific volume anomaly (right). Units are ${ }^{\circ} \mathrm{C}$ and $10^{-6} \mathrm{~m}^{3} \mathrm{~kg}^{-1}$.

Figure 3. (a) Groups of CTD temperature profiles for the SW region that have geopotential anomaly referenced to $1000 \mathrm{dbar}\left(\phi_{1000}\right)$ values within $0.2 \mathrm{~m}^{2} \mathrm{~s}^{-2}$ of the five indicated central values, progressively shifted to the right by $5^{\circ} \mathrm{C}$. The bold dashed curves are the corresponding GEM temperature profiles. (b) Percent of variance in temperature (solid line) and specific volume anomaly (dashed line) captured by the GEM fields for each subregion.

Figure 4. (a) Locations of RAFOS (light gray dots) and MARVOR (dark gray dots) float data for the South Atlantic Ocean. Smaller black dots in the western side of the basin represent three WOCE transects HL (top) A17 (bottom left) and A23 (bottom right). (b) Number of float data points per $1^{\circ} \times 1^{\circ}$ bin for the western and eastern regions used to calculate the map of transport streamfunction. In each panel, the two rectangles outline the western and eastern areas from which float data are used in this study.

Figure 5. Diagram illustrating the float-GEM technique. The streamfunction value $\left(\phi_{f l o a t}\right)$ corresponding to a given float station is found by looking up the $\left(p_{\text {float }}, T_{\text {float }}\right)$ pair on the temperature GEM field (left panel). Once $\phi_{f l o a t}$ is known, it is used to estimate the specific 
volume anomaly profile from its respective GEM field (middle panel). Then, the estimated specific volume anomaly profile is obtained and plotted in the right panel. The diagram also illustrates the float-GEM error associated with errors in the float temperature measurement ( $\left.\varepsilon T_{\text {float }}\right)$ generating an uncertainty in the determination of the streamfunction value $\left(\phi_{\text {float }} \pm \varepsilon \phi_{\text {float }}\right)$ (left panel), which in turn generates an uncertainty in the estimate of the specific volume anomaly profile (middle and right panels). See Appendix B for details on the float-GEM errors.

Figure 6. Schematic representation of the calculation involving the baroclinic and barotropic components of the velocity. Note: here "true barotropic velocity" means abyssal velocity.

Figure 7. Measured (solid line) and GEM-simulated (dashed line) profiles of (a) temperature and (b) specific volume anomaly for 6 representative stations of the WOCE A17 transect (see Fig. 4a). Profiles progressively offset as indicated.

Figure 8. Baroclinic velocity across the selected section of the WOCE A17 transect for the upper 1000 dbar calculated from (a) the real specific volume anomaly profiles, (b) the GEM-generated profiles, and (c) the difference between them. Positive values represent southeastward flow. Distance is measured from the southwestern end of the transect line (see Fig. 4a). Contours are every $5 \mathrm{~cm} \mathrm{~s}^{-1}$. Triangles in the bottom panel represent locations of stations.

Figure 9. (a) Baroclinic, (b) barotropic, and (c) total mass transport streamfunctions for the top $1000 \mathrm{dbar}$ (in units of $\left.10^{5} \mathrm{~kg} \mathrm{~s}^{-2}\right)$. Contours are every $5 \times 10^{5} \mathrm{~kg} \mathrm{~s}^{-2}\left(2.5 \times 10^{5} \mathrm{~kg} \mathrm{~s}^{-2}\right)$ for thick (thin) contours. Solid lines (labeled in panel a) show sections where current transport estimates are given in the text in Section 4 and Table 2. Right panels represent the mass transport, in units of $10^{9} \mathrm{~kg} \mathrm{~s}^{-1}\left(\sim 10^{6} \mathrm{~m}^{3} \mathrm{~s}^{-1}=1 \mathrm{~Sv}\right)$, corresponding to the streamfunction contour interval of $5 \times 10^{5} \mathrm{~kg}$ $s^{-2}$. 
Figure 10. (a) Baroclinic, (b) barotropic, and (c) total volume transport through $1^{\circ} \times 1^{\circ}$ cells for the top $1000 \mathrm{dbar}$, in units of $10^{6} \mathrm{~m}^{3} \mathrm{~s}^{-1}=1 \mathrm{~Sv}$.

Figure 11. Schematic illustration of the total volume transport partition for the top $1000 \mathrm{dbar}$, in units of $10^{6} \mathrm{~m}^{3} \mathrm{~s}^{-1}=1 \mathrm{~Sv}$. Arrows represent the transports and are colored according to their origins. Gray shaded area represents the region where waters from both Pacific and Indian oceans interact. 
Table 1: Baroclinic mass transport across $36^{\circ} \mathrm{W}$ for the top 1000 dbar obtained by taking the horizontal gradient of the baroclinic streamfunction $\chi$ before dividing by the local Coriolis parameter $f$ given by $M_{i}=\left(\chi_{i+1}-\chi_{i}\right) /\left|f_{i+1 / 2}\right|$, where $f_{i+1 / 2}=\left(f_{i}+f_{i+1}\right) / 2$; and after dividing by $f$ given by $M_{i}^{\prime}=\left(\chi_{i+1} / \mid f_{i+1}\right)-\left(\chi_{i} /\left|f_{i}\right|\right)$. Units are $10^{-4} \mathrm{~s}^{-1}$ for $f, 10^{5} \mathrm{~kg} \mathrm{~s}^{-2}$ for $\chi$, and $10^{9} \mathrm{~kg} \mathrm{~s}^{-1}$ for $M$, $\chi / f$, and $M^{\prime} . M$ is the correct formulation, since $\chi$ is the correct streamfunction. Baroclinic mass transports in the last row represent sums over the range $25-43^{\circ} \mathrm{S}$. Index $i$ is the row number, increasing downward (northward).

\begin{tabular}{cccccccc}
\hline Latitude & $\left|f_{i}\right|$ & $\left|f_{i+1 / 2}\right|$ & $\chi_{i}$ & $\chi_{i}\left|f_{i}\right|$ & $M_{i}$ & $M_{i}{ }^{\prime}$ & $M_{i}{ }^{\prime}-M_{i}$ \\
\hline $43^{\circ} \mathrm{S}$ & 0.995 & 0.985 & 40.54 & 40.76 & 2.39 & 3.20 & 0.81 \\
$42^{\circ} \mathrm{S}$ & 0.976 & 0.966 & 42.90 & 43.96 & 1.47 & 2.36 & 0.89 \\
$41^{\circ} \mathrm{S}$ & 0.957 & 0.947 & 44.32 & 46.32 & 3.56 & 4.56 & 1.00 \\
$40^{\circ} \mathrm{S}$ & 0.937 & 0.928 & 47.70 & 50.88 & 4.32 & 5.46 & 1.14 \\
$39^{\circ} \mathrm{S}$ & 0.918 & 0.908 & 51.71 & 56.34 & 1.32 & 2.59 & 1.27 \\
$38^{\circ} \mathrm{S}$ & 0.898 & 0.889 & 52.90 & 58.92 & 3.72 & 5.12 & 1.40 \\
$37^{\circ} \mathrm{S}$ & 0.878 & 0.867 & 56.21 & 64.04 & 0.38 & 1.91 & 1.53 \\
$36^{\circ} \mathrm{S}$ & 0.857 & 0.847 & 56.54 & 65.95 & 1.20 & 2.85 & 1.65 \\
$35^{\circ} \mathrm{S}$ & 0.836 & 0.826 & 57.56 & 68.81 & 3.88 & 5.70 & 1.82 \\
$34^{\circ} \mathrm{S}$ & 0.815 & 0.805 & 60.76 & 74.50 & 2.87 & 4.90 & 2.03 \\
$33^{\circ} \mathrm{S}$ & 0.794 & 0.784 & 63.07 & 79.41 & -0.88 & 1.31 & 2.19
\end{tabular}




\begin{tabular}{cccccccc}
$32^{\circ} \mathrm{S}$ & 0.773 & 0.762 & 62.38 & 80.72 & -2.23 & 0.07 & 2.30 \\
$31^{\circ} \mathrm{S}$ & 0.751 & 0.740 & 60.68 & 80.79 & -0.88 & 1.54 & 2.42 \\
$30^{\circ} \mathrm{S}$ & 0.729 & 0.718 & 60.03 & 82.33 & -2.03 & 0.52 & 2.55 \\
$29^{\circ} \mathrm{S}$ & 0.707 & 0.696 & 58.57 & 82.84 & 0.20 & 2.91 & 2.87 \\
$28^{\circ} \mathrm{S}$ & 0.685 & 0.673 & 58.71 & 85.75 & -2.96 & -0.09 & 3.03 \\
$27^{\circ} \mathrm{S}$ & 0.662 & 0.651 & 56.72 & 85.66 & -1.51 & 1.51 & 3.26 \\
$26^{\circ} \mathrm{S}$ & 0.639 & 0.628 & 55.73 & 87.17 & 0.69 & 3.96 & $\sum M_{i}^{\prime}-M_{i} \approx 35$ \\
$25^{\circ} \mathrm{S}$ & 0.616 & & 56.17 & 91.13 & $\sum M_{i} \approx 15$ & $\sum M_{i}^{\prime} \approx 50$ & \\
\hline
\end{tabular}


Table 2: Baroclinic, barotropic, and total mass transports for the top $1000 \mathrm{dbar}$ across selected sections discussed in Section 4 and shown in Figure 9. Units are $10^{9} \mathrm{~kg} \mathrm{~s}^{-1}$ (approximately equivalent to $10^{6} \mathrm{~m}^{3} \mathrm{~s}^{-1}=1 \mathrm{~Sv}$ volume transport).

\begin{tabular}{|c|c|c|c|c|}
\hline $\begin{array}{l}\text { Section } \\
\text { Current }\end{array}$ & Location & Baroclinic & Barotropic & Total \\
\hline $\begin{array}{c}\text { A } \\
\text { Brazil Current }\end{array}$ & $\begin{array}{c}20^{\circ} \mathrm{S} \\
\left(39^{\circ} \mathrm{W}-34^{\circ} \mathrm{W}\right)\end{array}$ & 10.5 & 10.2 & 20.7 \\
\hline $\begin{array}{c}\text { B } \\
\text { Brazil Current }\end{array}$ & $\begin{array}{c}25^{\circ} \mathrm{S} \\
\left(46^{\circ} \mathrm{W}-41^{\circ} \mathrm{W}\right)\end{array}$ & -10.7 & 8.0 & -2.7 \\
\hline $\begin{array}{c}\text { C } \\
\text { Brazil Current }\end{array}$ & $\begin{array}{c}30^{\circ} \mathrm{S} \\
\left(49^{\circ} \mathrm{W}-46^{\circ} \mathrm{W}\right)\end{array}$ & -11.2 & -9.7 & -20.9 \\
\hline $\begin{array}{c}\text { D } \\
\text { Brazil Current }\end{array}$ & $\begin{array}{c}35^{\circ} \mathrm{S} \\
\left(53^{\circ} \mathrm{W}-50^{\circ} \mathrm{W}\right)\end{array}$ & -8.3 & -37.7 & -46.0 \\
\hline $\begin{array}{c}E \\
\text { SAC }\end{array}$ & $\begin{array}{c}50^{\circ} \mathrm{W} \\
\left(42^{\circ} \mathrm{S}-35^{\circ} \mathrm{S}\right) \\
\left(40^{\circ} \mathrm{S}-38^{\circ} \mathrm{S}\right)\end{array}$ & $\begin{array}{r}20.3 \\
6.4\end{array}$ & $\begin{array}{l}11.3 \\
39.4\end{array}$ & $\begin{array}{l}31.6 \\
45.8\end{array}$ \\
\hline $\begin{array}{c}\text { F } \\
\text { SAC }\end{array}$ & $\begin{array}{c}30^{\circ} \mathrm{W} \\
\left(44^{\circ} \mathrm{S}-37^{\circ} \mathrm{S}\right)\end{array}$ & 17.6 & 32.4 & 50.0 \\
\hline $\begin{array}{c}\mathrm{G} \\
\text { SAC }\end{array}$ & $\begin{array}{l}0^{\circ} \text { longitude } \\
\left(39^{\circ} \mathrm{S}-36^{\circ} \mathrm{S}\right)\end{array}$ & 8.7 & 10.3 & 19.0 \\
\hline $\begin{array}{l}\mathrm{H} \\
\text { SAC }\end{array}$ & $\begin{array}{l}0^{\circ} \text { longitude } \\
\left(47^{\circ} \mathrm{S}-43^{\circ} \mathrm{S}\right)\end{array}$ & -1.0 & 32.0 & 31.0 \\
\hline$\stackrel{\mathrm{I}}{\mathrm{ACR}^{*}}$ & $\begin{array}{c}39^{\circ} \mathrm{S} \\
\left(10^{\circ} \mathrm{E}-22^{\circ} \mathrm{E}\right)\end{array}$ & -10.7 & -37.3 & -48.0 \\
\hline$\stackrel{\mathrm{J}}{\text { Benguela Current }}$ & $\begin{array}{c}33^{\circ} \mathrm{S} \\
\left(8^{\circ} \mathrm{E}-12^{\circ} \mathrm{E}\right) \\
\left(12^{\circ} \mathrm{E}-17^{\circ} \mathrm{E}\right)\end{array}$ & $\begin{array}{r}3.6 \\
12.0\end{array}$ & $\begin{array}{l}11.4 \\
-3.5\end{array}$ & $\begin{array}{r}15.0 \\
8.5\end{array}$ \\
\hline $\begin{array}{c}\text { K } \\
\text { Benguela Current }\end{array}$ & $\begin{array}{c}3^{\circ} \mathrm{E} \\
\left(32^{\circ} \mathrm{S}-27^{\circ} \mathrm{S}\right)\end{array}$ & 2.4 & -17.4 & -15.0 \\
\hline
\end{tabular}


*ACR stands for Agulhas Current Retroflection. 
Table B1. Errors involved in estimates of the mass transport for the western basin. $U_{\text {float }}$ and $V_{\text {float }}$ are respectively the zonal and meridional component of the Lagrangian velocity; $\psi_{\text {float }}$ refers to the streamfunction on the standard float level; $\psi^{\prime}$ to the geopotential anomaly at 800 dbar referenced to $1000 \mathrm{dbar}$; and $\chi$ to the potential energy anomaly; $\vec{M}_{1000}^{b c}, \vec{M}_{1000}^{b t}$, and $\vec{M}_{1000}^{\text {total }}$ are the baroclinic, barotropic, and total mass transports for the top $1000 \mathrm{dbar}$, respectively.

\begin{tabular}{lcccc}
\hline Variable & $\begin{array}{c}\text { Float-GEM Error } \\
\left(\varepsilon_{f g}\right)\end{array}$ & $\begin{array}{c}\text { Binning Error } \\
\left(\varepsilon_{b}\right)\end{array}$ & $\begin{array}{c}\text { Total Error } \\
(E)\end{array}$ & Units \\
\hline$f U_{\text {float }} \Delta y$ & 0.15 & 0.23 & 0.28 & $\mathrm{~m}^{2} \mathrm{~s}^{-2}$ \\
$f V_{\text {float }} \Delta x$ & 0.11 & 0.21 & 0.24 & $\mathrm{~m}^{2} \mathrm{~s}^{-2}$ \\
$\psi_{\text {float }}$ & 0.13 & 0.22 & 0.26 & $\mathrm{~m}^{2} \mathrm{~s}^{-2}$ \\
$\psi^{\prime}$ & 0.02 & 0.01 & 0.02 & $\mathrm{~m}^{2} \mathrm{~s}^{-2}$ \\
$\chi$ & 1.56 & 0.99 & 1.85 & $10^{5} \mathrm{~kg} \mathrm{~s}^{-2}$ \\
$\vec{M}_{1000}^{b c}$ & 1.56 & 0.99 & 1.85 & $10^{9} \mathrm{~kg} \mathrm{~s}^{-1}$ \\
$\vec{M}_{1000}^{b t}$ & 1.33 & 2.27 & 2.63 & $10^{9} \mathrm{~kg} \mathrm{~s}^{-1}$ \\
$\vec{M}_{1000}^{\text {total }}$ & 2.18 & 2.60 & 3.39 & $10^{9} \mathrm{~kg} \mathrm{~s}^{-1}$ \\
\hline
\end{tabular}


Table B2. Same as Table B1 except for the eastern basin.

\begin{tabular}{lcccc}
\hline Variable & $\begin{array}{c}\text { Float-GEM Error } \\
\left(\varepsilon_{f g}\right)\end{array}$ & $\begin{array}{c}\text { Binning Error } \\
\left(\varepsilon_{b}\right)\end{array}$ & $\begin{array}{c}\text { Total Error } \\
(E)\end{array}$ & Units \\
\hline$f U_{\text {float }} \Delta y$ & 0.22 & 0.30 & 0.37 & $\mathrm{~m}^{2} \mathrm{~s}^{-2}$ \\
$f V_{\text {float }} \Delta x$ & 0.15 & 0.20 & 0.25 & $\mathrm{~m}^{2} \mathrm{~s}^{-2}$ \\
$\psi_{\text {float }}$ & 0.19 & 0.25 & 0.32 & $\mathrm{~m}^{2} \mathrm{~s}^{-2}$ \\
$\psi^{\prime}$ & 0.02 & 0.01 & 0.02 & $\mathrm{~m}^{2} \mathrm{~s}^{-2}$ \\
$\chi$ & 1.10 & 0.96 & 1.46 & $10^{5} \mathrm{~kg} \mathrm{~s}^{-2}$ \\
$\vec{M}_{1000}^{b c}$ & 1.10 & 0.96 & 1.46 & $10^{9} \mathrm{~kg} \mathrm{~s}^{-1}$ \\
$\vec{M}_{1000}^{b t}$ & 1.94 & 2.56 & 3.21 & $10^{9} \mathrm{~kg} \mathrm{~s}^{-1}$ \\
$\vec{M}_{1000}^{\text {total }}$ & 2.25 & 2.78 & 38 & $10^{9} \mathrm{~kg} \mathrm{~s}^{-1}$ \\
\hline
\end{tabular}




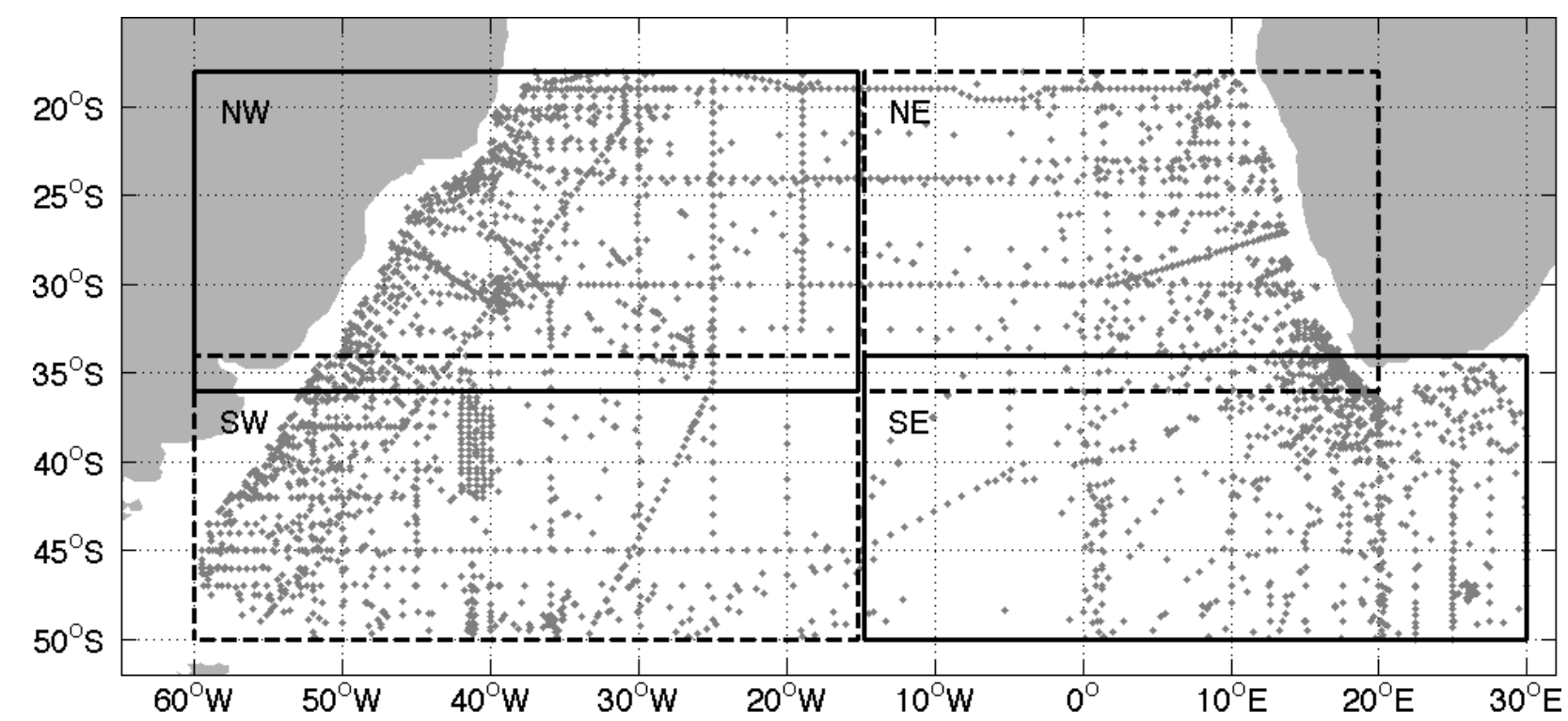

Figure 1. Subregions selected for the construction of the GEM fields. Dots represent the CTD and bottle cast locations used from HydroBase and AWI data sets. 

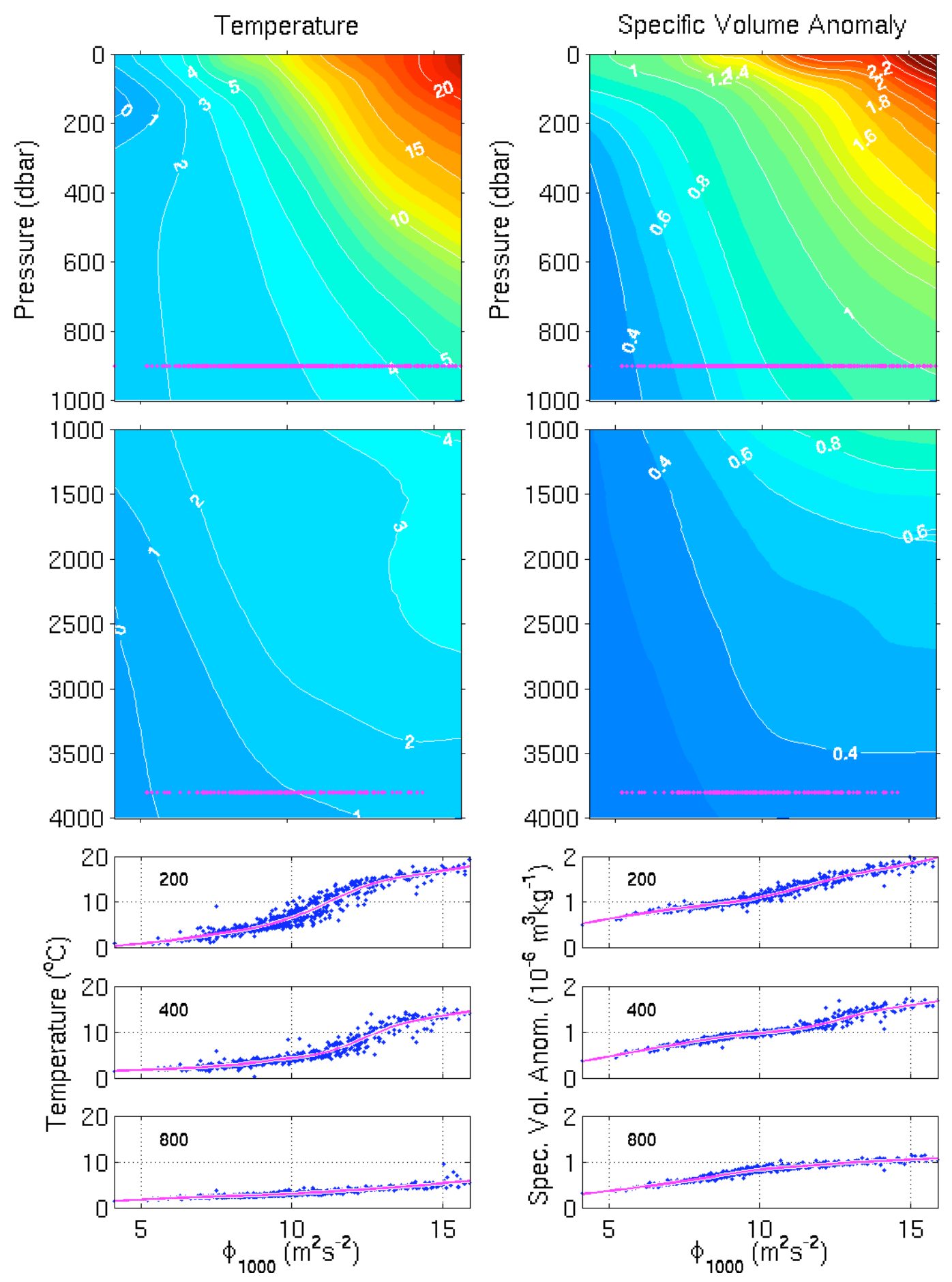

Figure 2. The final smooth GEM fields of temperature (top left) and specific volume anomaly (top right) for the SW region. Dots at $900 \mathrm{dbar}$ and $3800 \mathrm{dbar}$ indicate station locations in streamfunction space. Bottom six panels show the data and their smoothing spline fits at 200, 400, and $800 \mathrm{dbar}$ for temperature (left) and specific volume anomaly (right). Units are ${ }^{\circ} \mathrm{C}$ and $10^{-6} \mathrm{~m}^{3} \mathrm{~kg}^{-1}$. 

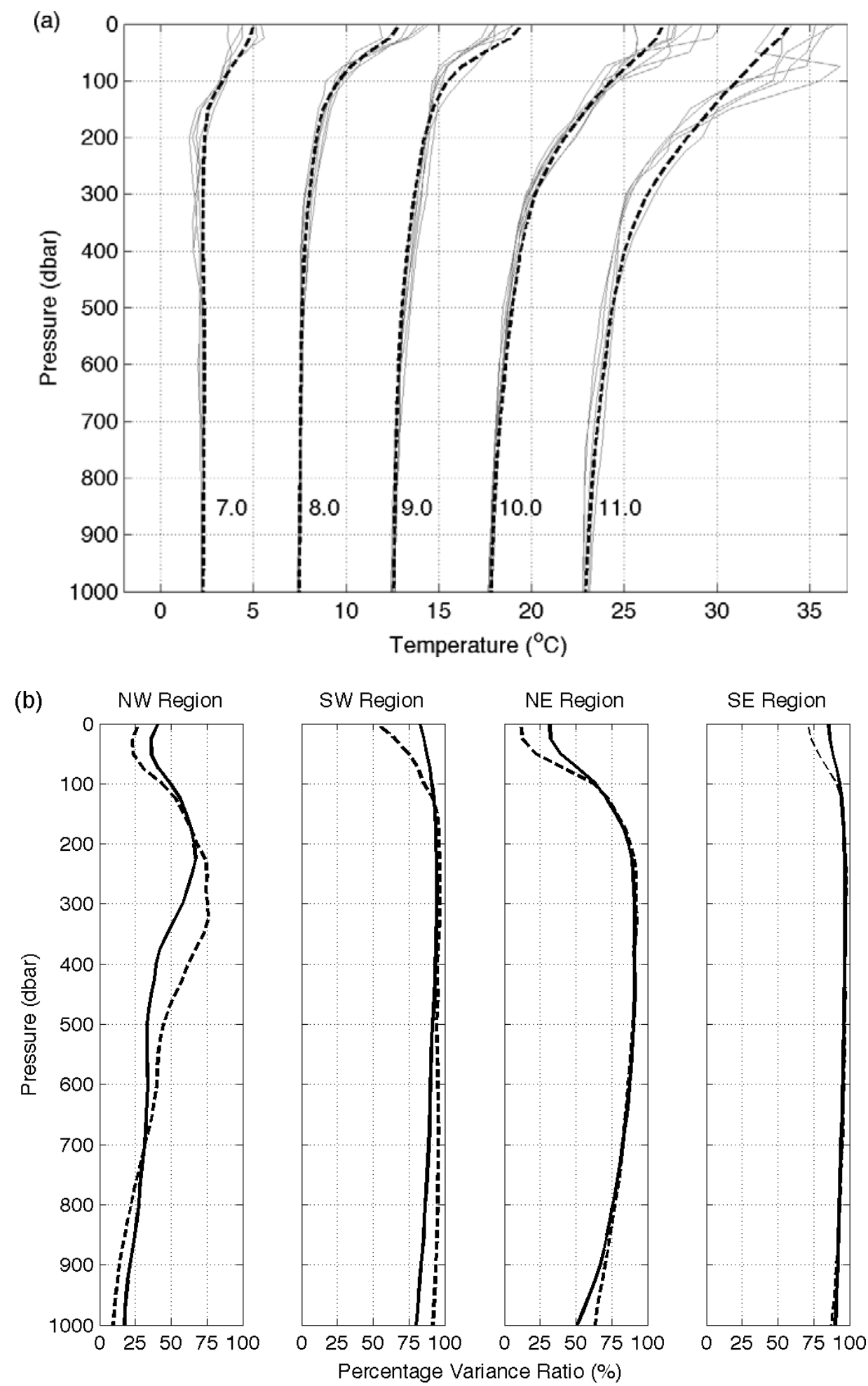

Figure 3. (a) Groups of CTD temperature profiles for the SW region that have geopotential anomaly referenced to $1000 \mathrm{dbar}\left(\phi_{1000}\right)$ values within $0.2 \mathrm{~m}^{2} \mathrm{~s}^{-2}$ of the five indicated central values, progressively shifted to the right by $5^{\circ} \mathrm{C}$. The bold dashed curves are the corresponding GEM temperature profiles. (b) Percent of variance in temperature (solid line) and specific volume anomaly (dashed line) captured by the GEM fields for each subregion. 

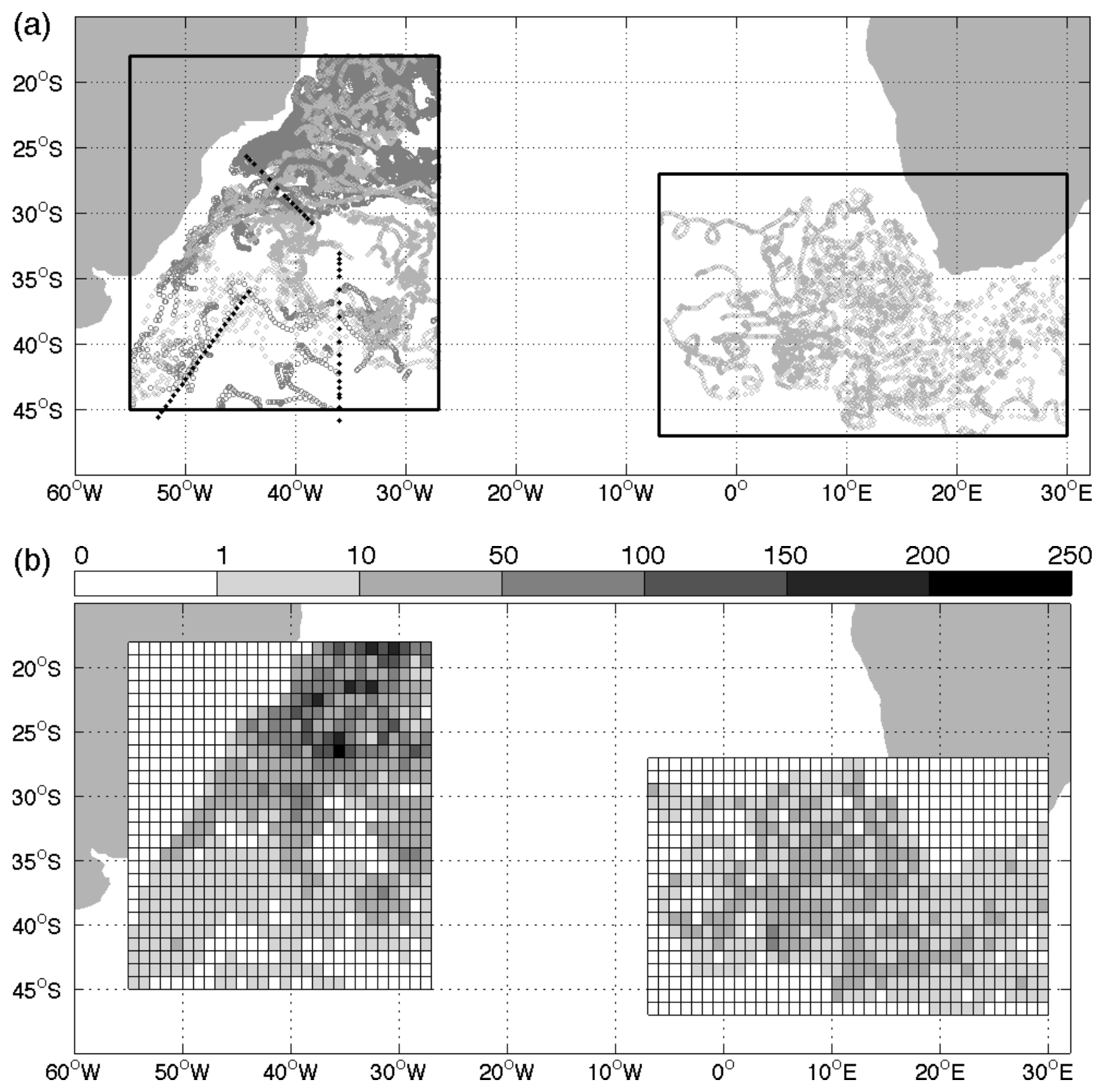

Figure 4. (a) Locations of RAFOS (light gray dots) and MARVOR (dark gray dots) float data for the South Atlantic Ocean. Smaller black dots in the western side of the basin represent three WOCE transects HL (top) A17 (bottom left) and A23 (bottom right). (b) Number of float data points per $1^{\circ} \times 1^{\circ}$ bin for the western and eastern regions used to calculate the map of transport streamfunction. In each panel, the two rectangles outline the western and eastern areas from which float data are used in this study. 


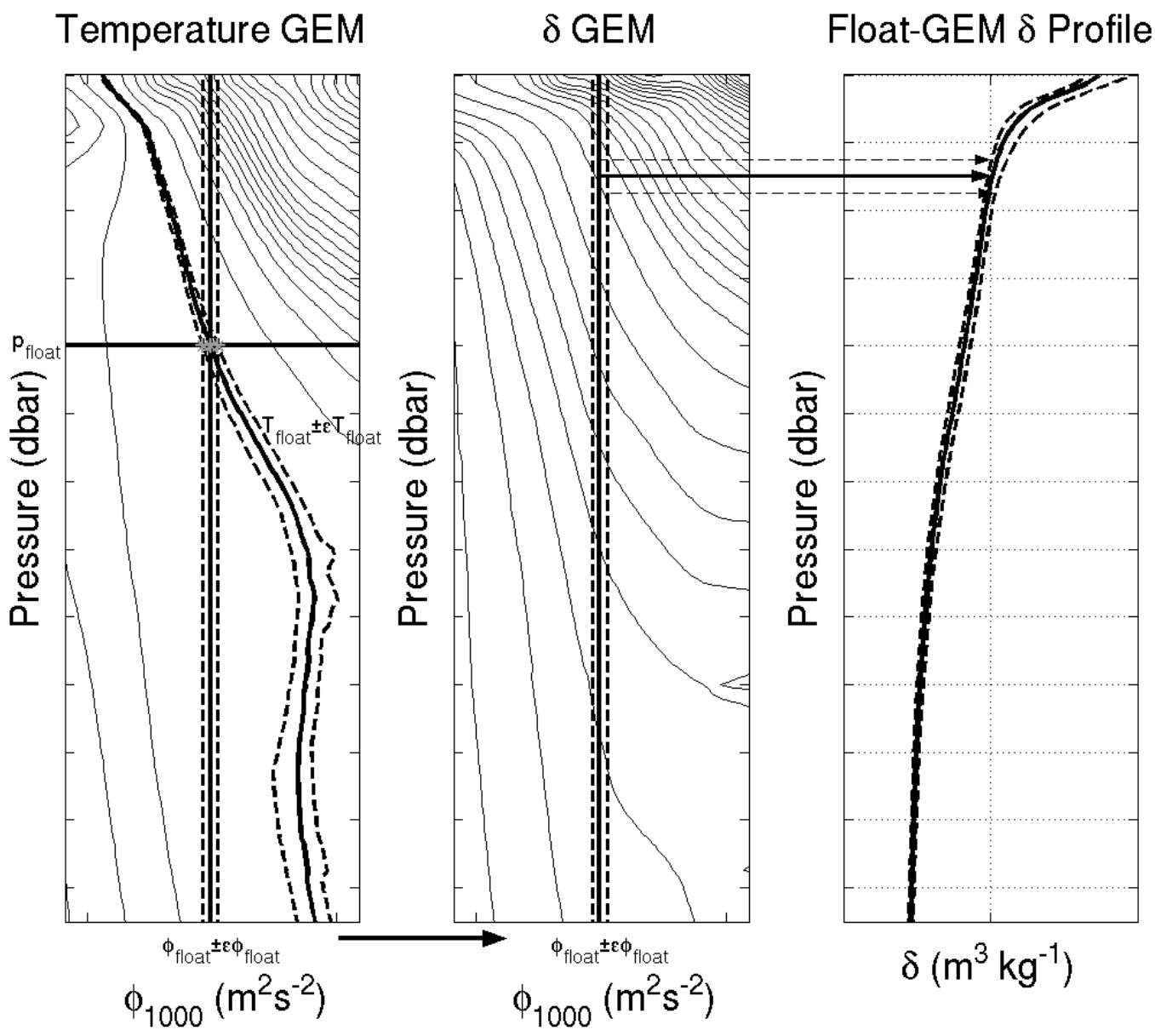

Figure 5. Diagram illustrating the float-GEM technique. The streamfunction value $\left(\phi_{f l o a t}\right)$ corresponding to a given float station is found by looking up the ( $\left.p_{\text {float }}, T_{\text {float }}\right)$ pair on the temperature GEM field (left panel). Once $\phi_{\text {float }}$ is known, it is used to estimate the specific volume anomaly profile from its respective GEM field (middle panel). Then, the estimated specific volume anomaly profile is obtained and plotted in the right panel. The diagram also illustrates the float-GEM error associated with errors in the float temperature measurement $\left(\varepsilon T_{\text {float }}\right)$ generating an uncertainty in the determination of the streamfunction value $\left(\phi_{\text {float }} \pm \varepsilon \phi_{\text {float }}\right)$ (left panel), which in turn generates an uncertainty in the estimate of the specific volume anomaly profile (middle and right panels). See Appendix B for details on the float-GEM errors. 


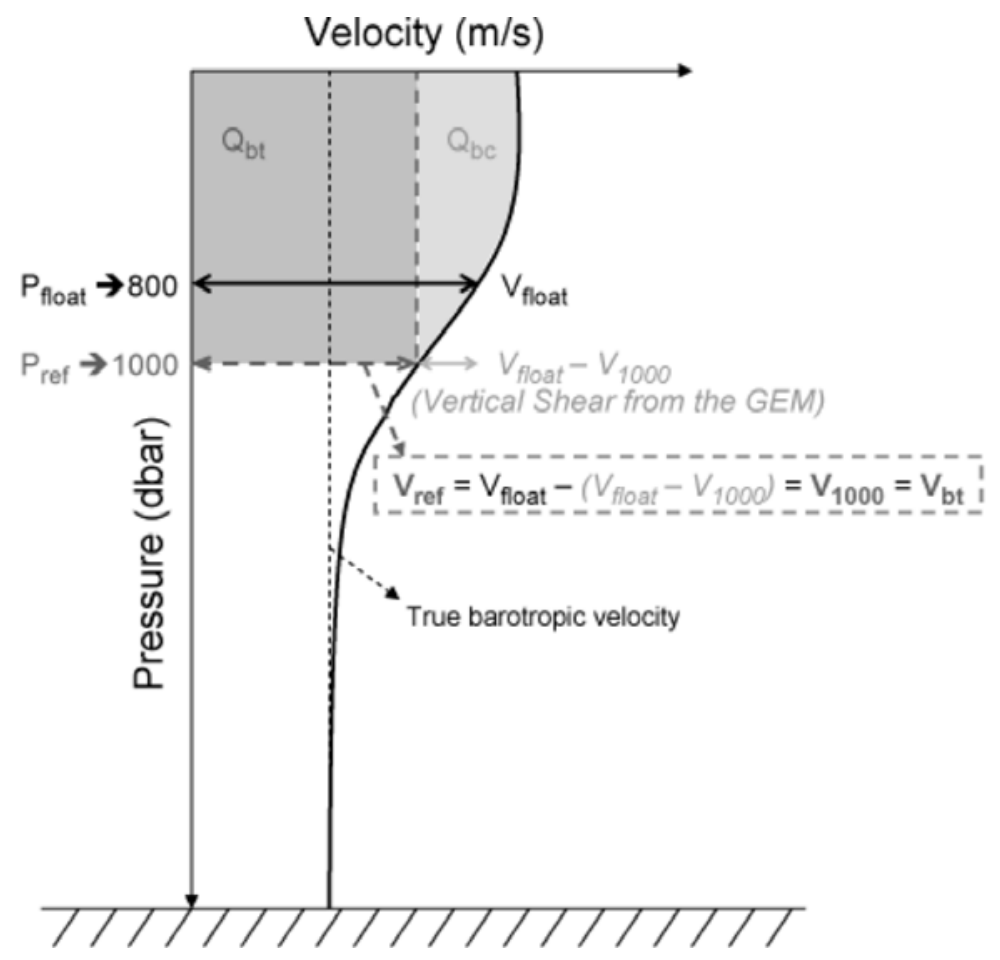

Figure 6. Schematic representation of the calculation involving the baroclinic and barotropic components of the velocity. Note: here "true barotropic velocity" means abyssal velocity. 

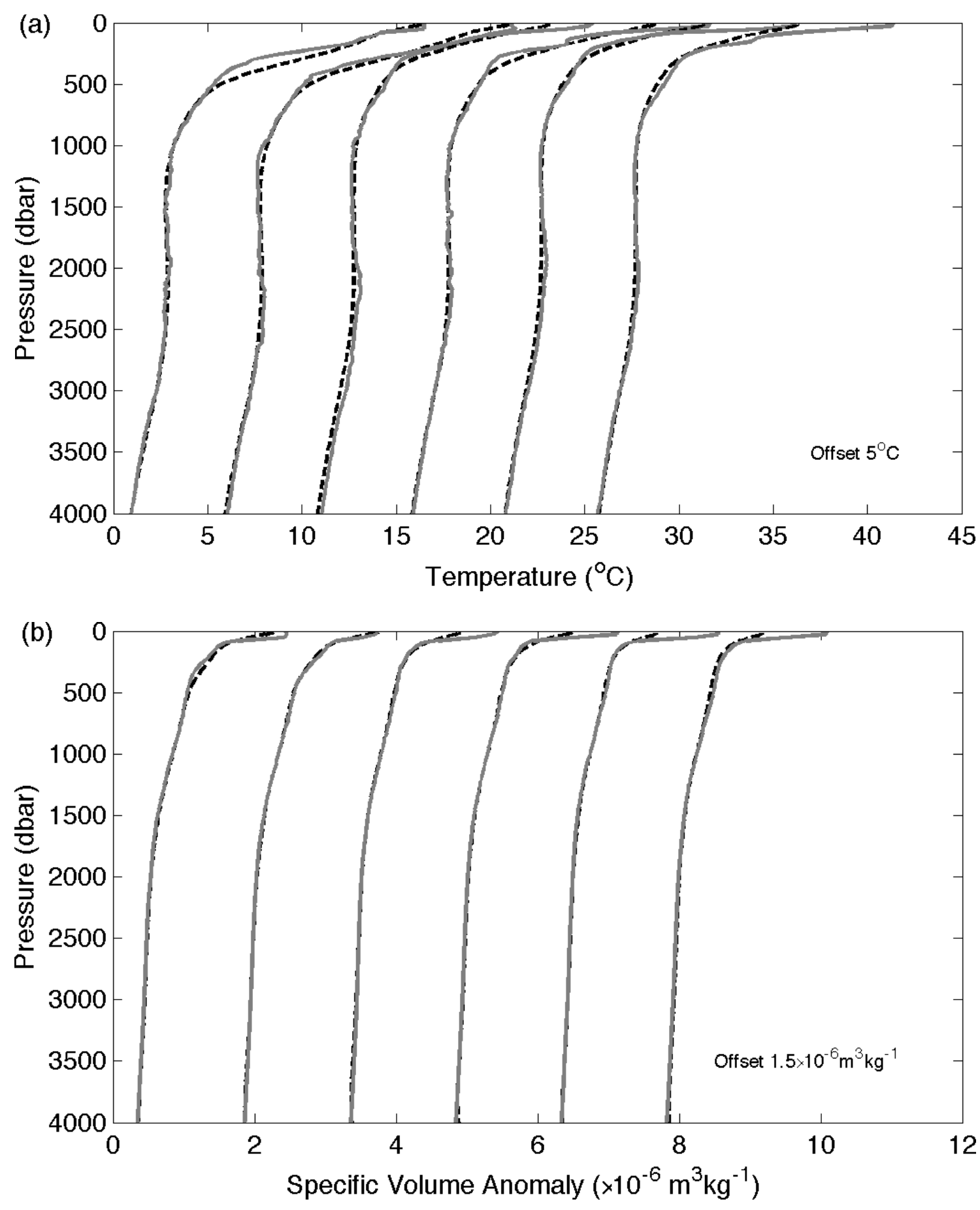

Figure 7. Measured (solid line) and GEM-simulated (dashed line) profiles of (a) temperature and (b) specific volume anomaly for 6 representative stations of the WOCE A17 transect (see Fig. 4a). Profiles progressively offset as indicated. 

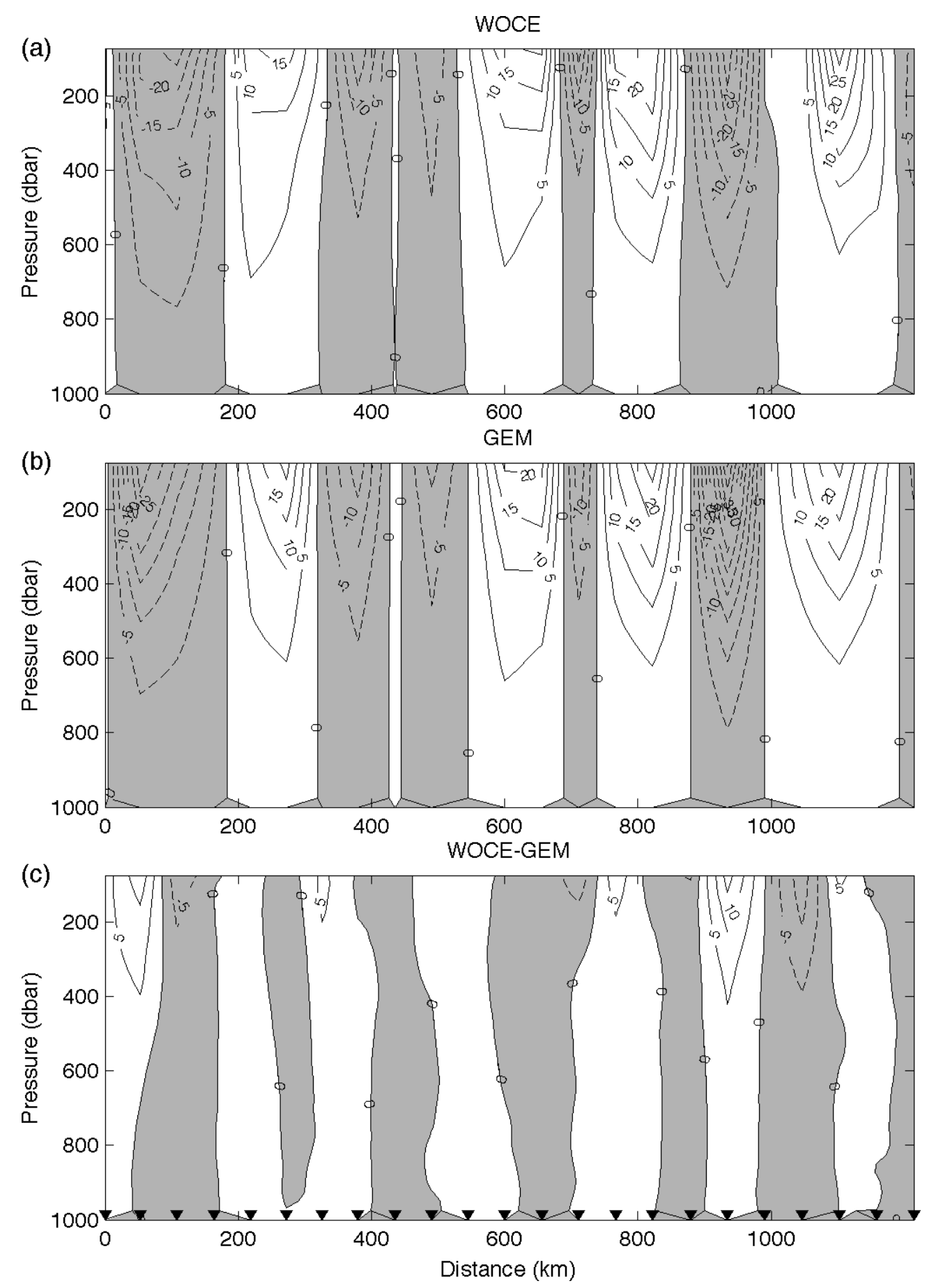

Figure 8. Baroclinic velocity across the selected section of the WOCE A17 transect for the upper 1000 dbar calculated from (a) the real specific volume anomaly profiles, (b) the GEM-generated profiles, and (c) the difference between them. Positive values represent southeastward flow. Distance is measured from the southwestern end of the transect line (see Fig. 4a). Contours are every $5 \mathrm{~cm} \mathrm{~s}^{-1}$. Triangles in the bottom panel represent locations of stations. 

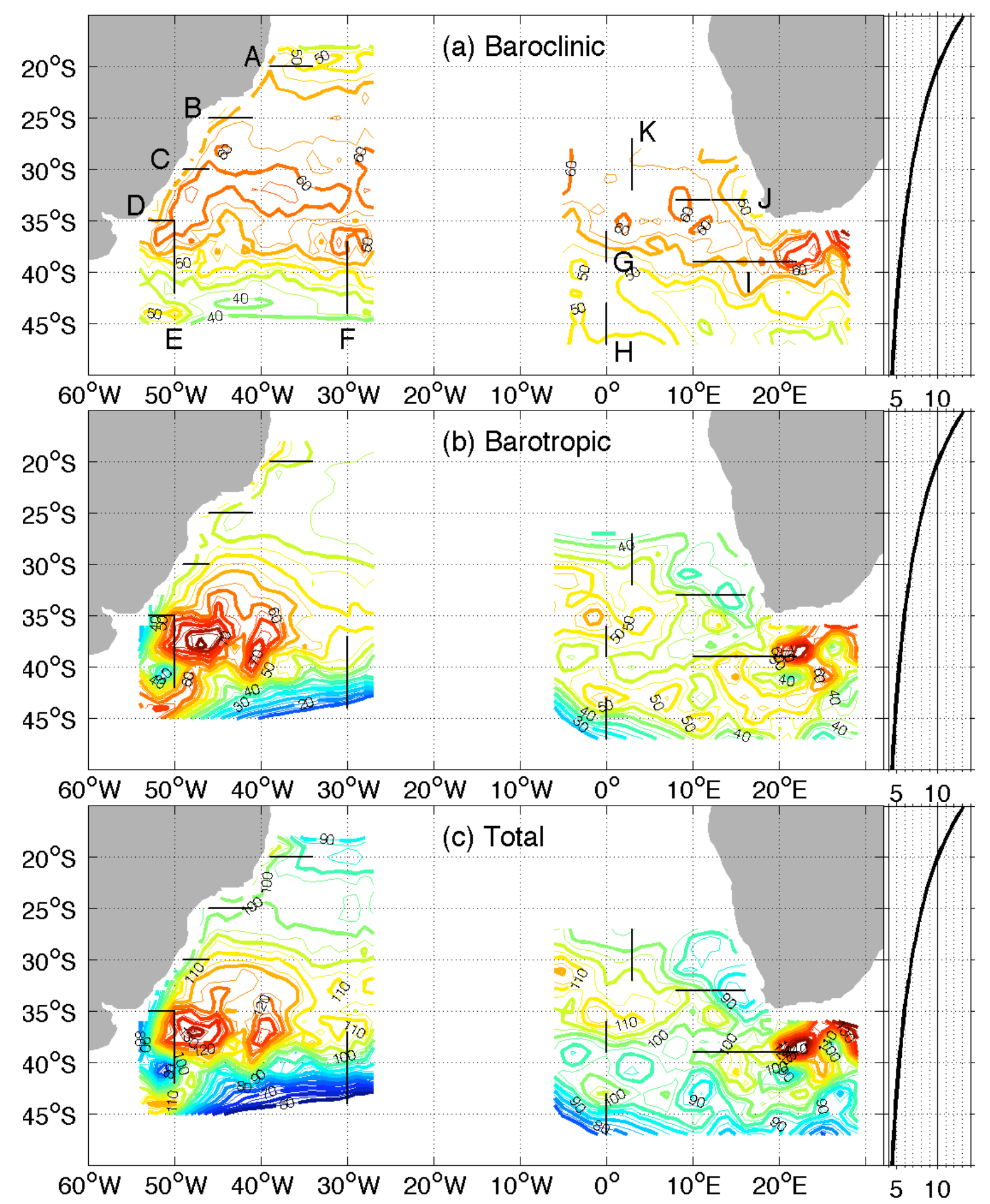

Figure 9. (a) Baroclinic, (b) barotropic, and (c) total mass transport streamfunctions for the top 1000 dbar (in units of $\left.10^{5} \mathrm{~kg} \mathrm{~s}^{-2}\right)$. Contours are every $5 \times 10^{5} \mathrm{~kg} \mathrm{~s}^{-2}\left(2.5 \times 10^{5} \mathrm{~kg} \mathrm{~s}^{-2}\right)$ for thick (thin) contours. Solid lines (labeled in panel a) show sections where current transport estimates are given in the text in Section 4 and Table 2. Right panels represent the mass transport, in units of $10^{9} \mathrm{~kg} \mathrm{~s}^{-1}\left(\sim 10^{6} \mathrm{~m}^{3} \mathrm{~s}^{-1}=1 \mathrm{~Sv}\right)$, corresponding to the streamfunction contour interval of $5 \times 10^{5} \mathrm{~kg}$ $\mathrm{s}^{-2}$. 

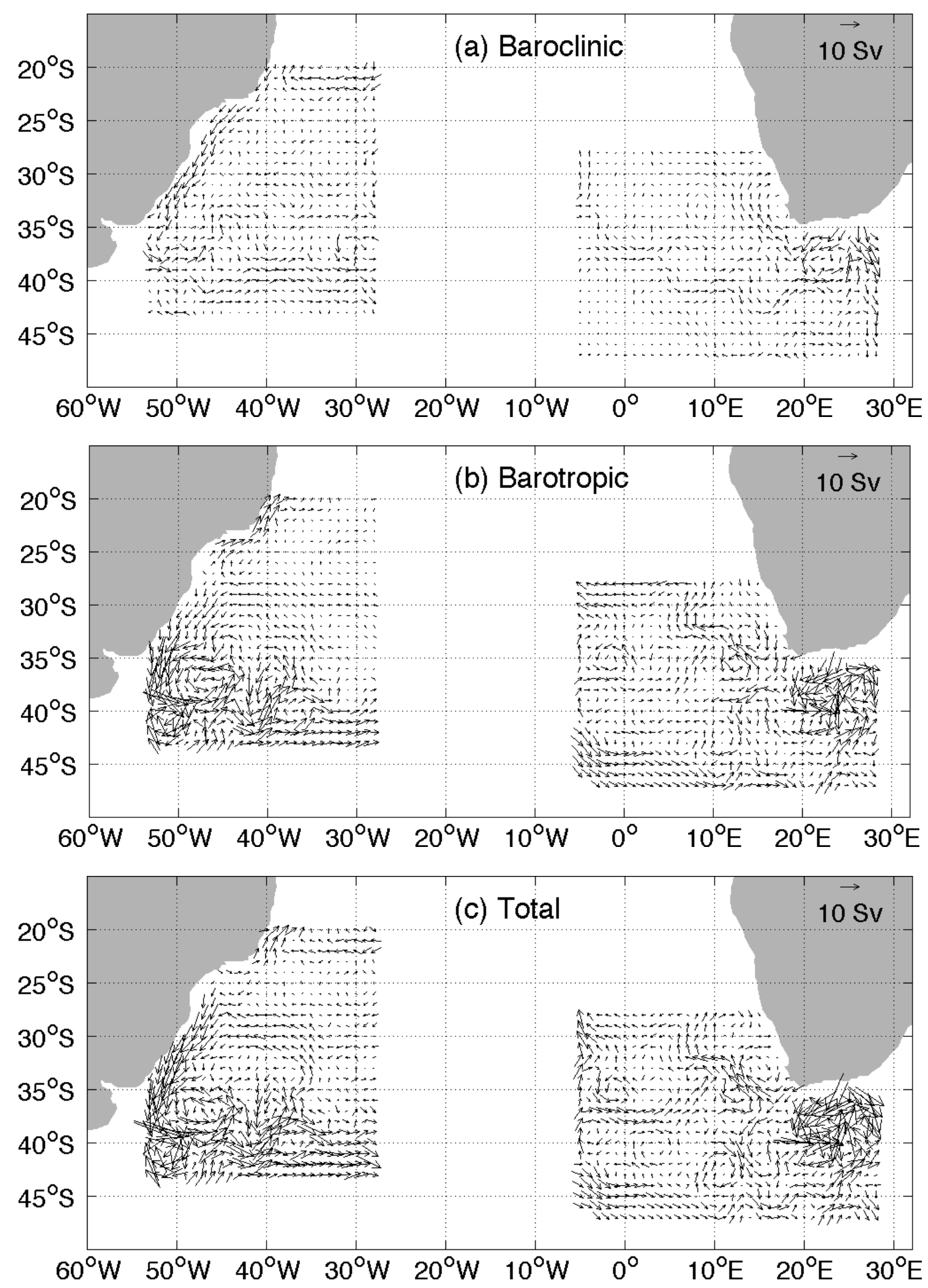

Figure 10. (a) Baroclinic, (b) barotropic, and (c) total volume transport through $1^{\circ} \times 1^{\circ}$ cells for the top $1000 \mathrm{dbar}$, in units of $10^{6} \mathrm{~m}^{3} \mathrm{~s}^{-1}=1 \mathrm{~Sv}$. 


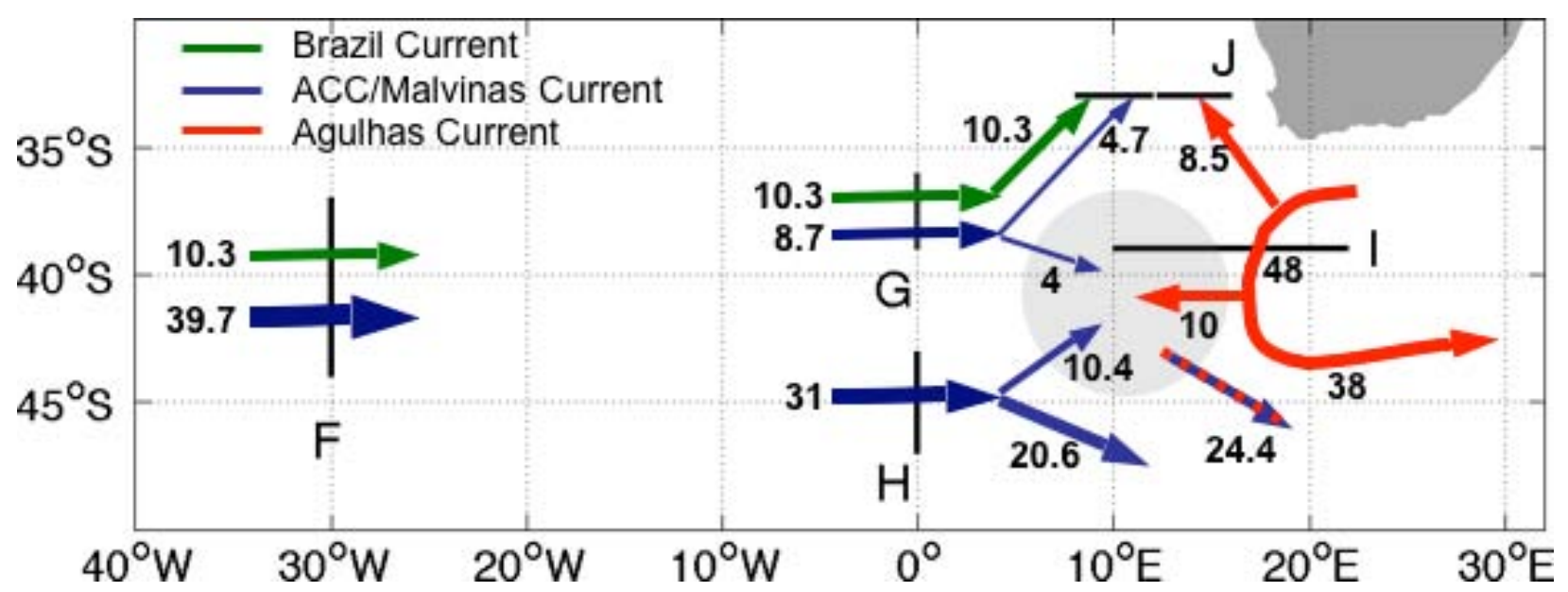

Figure 11. Schematic illustration of the total volume transport partition for the top $1000 \mathrm{dbar}$, in units of $10^{6} \mathrm{~m}^{3} \mathrm{~s}^{-1}=1 \mathrm{~Sv}$. Arrows represent the transports and are colored according to their origins. Gray shaded area represents the region where waters from both Pacific and Indian Oceans interact. 